\title{
BIS(CYCLOPENTADIENYL TRANSITION METAL) COMPLEXES RICH IN SULFUR
}

\author{
JOACHIM WACHTER \\ Institut für Anorganische Chemie der Universität Universitätsstraße 31 D-8400 Regensburg, FRG \\ (Received January 14, 1986; in final form February 20, 1986)
}

Synthetic techniques for the incorporation of elemental sulfur into dimeric cyclopentadienyl transition metals are reported. The resulting sulfur rich complexes ( $\mathrm{S} / \mathrm{M}$ ratio $\geqslant 2: 1$ ) differ significantly in their structures, depending on the nature of the metal. With the exception of the chromium triad only $3 \mathrm{~d}$ elements are concerned. The reactivity of the dicyclopentadienyl dimetal sulfides is localized both on the sulfur ligands and at the metal center as demonstrated by isomerization reactions and reactions with organic molecules. Some of these processes are of catalytic interest. The complexes $\left(\mathrm{MeC}_{5} \mathrm{H}_{4}\right)_{2} \mathrm{~V}_{2} \mathrm{~S}_{4},\left(\mathrm{C}_{5} \mathrm{Me}_{5}\right)_{2} \mathrm{Cr}_{2} \mathrm{~S}_{5}$ and $\left(\mathrm{C}_{5} \mathrm{Me}_{5}\right)_{2} \mathrm{Mo}_{2} \mathrm{~S}_{4}$ are useful substrates for the synthesis of tri- and tetra-nuclear clusters, the latter being first representatives of mixed metal heterocubanes with a $\mathbf{M}_{2} \mathbf{M}_{2}^{\prime} \mathbf{S}_{4}$ core. In a short chapter the present knowledge on cyclopentadienyl complexes containing other chalcogenides is summarized.

Key words: Sulfur complexes, synthesis, structure, reactivity

\section{INTRODUCTION}

Inorganic chalcogen ligands have become very attractive in transition metal chemistry during the last few years. Whereas the incorporation of the elements oxygen, selenium and tellurium seems to be at the very beginning, the coordination chemistry of sulfur ligands is already well developed. Several reviews dealing with mono-, di-, and polysulfur ligands have already been published. ${ }^{1-3}$

A new field in this chemistry involves the combination of mono- and disulfur ligands by cyclopentadienyl transition metal fragments, leading in most cases to the formation of dinuclear compounds comprising four or five sulfur atoms. In spite of their rather simple formulas these compounds exhibit interesting structural aspects as shown in Scheme 1. Their structures as well as the reactivity of the sulfur ligands vary significantly with the nature of the metal. In this review the syntheses and structures of these compounds will be described along with some chemical aspects, e.g. isomerization reactions, reactions with organic molecules, and the easy and systematic access of polynuclear sulfide clusters.

Scheme 1. Various Structure Types of $\mathrm{Cp}_{2} \mathbf{M}_{2} \mathrm{~S}_{4}$-Complexes
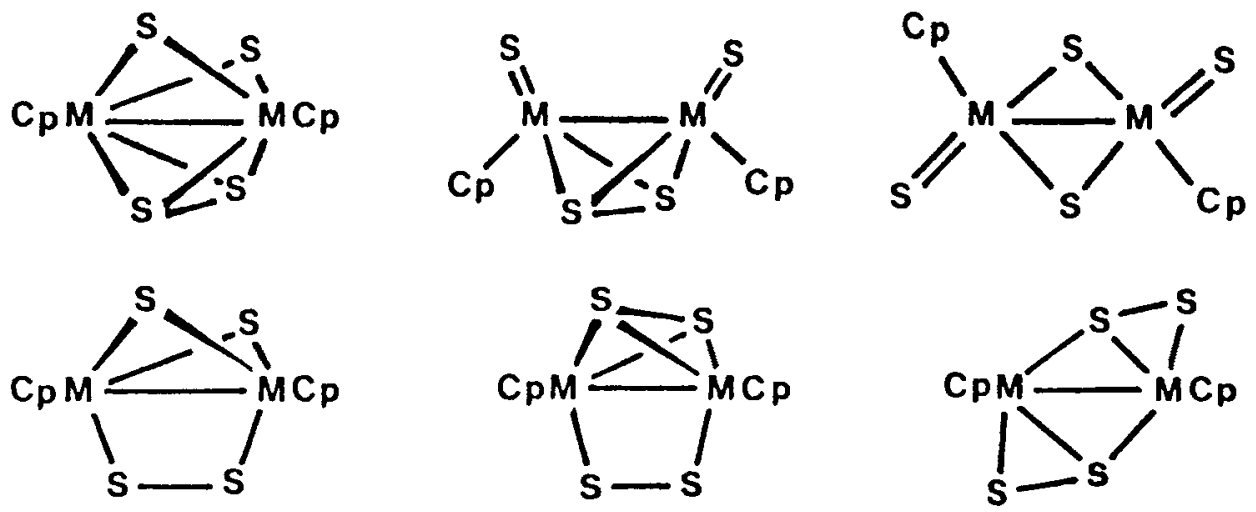


\section{SYNTHESES AND STRUCTURES}

Various organic and inorganic sulfur containing compounds have been used as sulfur transfer reagents to transition metal carbonyls, ${ }^{1}$ but in most cases they work accidentally and often lead to unexpected products. The most suitable substrates for the synthesis of $\mathrm{Cp}_{2} \mathrm{M}_{2} \mathrm{~S}_{\mathrm{x}}$ complexes are dimeric cyclopentadienyl carbonyl complexes in their reaction with elemental sulfur. First attempts to introduce elemental sulfur into such compounds led to insoluble products when $\mathrm{C}_{5} \mathrm{H}_{5} \mathrm{~V}(\mathrm{CO})_{4}$ or $\left[\mathrm{C}_{5} \mathrm{H}_{5} \mathrm{Mo}(\mathrm{CO})_{3}\right]_{2}$ were used as starting material. ${ }^{4}$ Somewhat more promising seemed to be the reaction of $\left[\mathrm{C}_{5} \mathrm{H}_{3} \mathrm{Fe}(\mathrm{CO})_{2}\right]_{2}$ with $\mathrm{S}_{8}$ in boiling toluene, which led to the cubane-like cluster $\left(\mathrm{C}_{5} \mathrm{H}_{5}\right)_{4} \mathrm{~S}_{4}{ }^{4}$ In the following years it was shown that these reactions could be optimized by the introduction of substituents at the cyclopentadienyl rings or by a modification of the reaction conditions. A summary of all sulfur rich $\mathrm{Cp}$ dimers cited in this article, along with the sulfur ligand set typical for each compound, is given in Table I.

\subsection{Vanadium and Niobium Compounds}

Two vanadium containing complexes of formulas $C \mathrm{p}_{2} \mathrm{~V}_{2} \mathrm{~S}_{4}$ and $\mathrm{Cp}_{2} \mathrm{~V}_{2} \mathrm{~S}_{3}$ are known, the latter of which is directly accessible from the thermal desulfurization of $\mathrm{Cp}_{2} \mathrm{VS}_{5}{ }^{5}$ Their structural characterization is only possible in the case of alkyl-substituted cyclopentadienyl rings. 6 As it has been shown by thermolytic studies on the related $\mathrm{Cp}_{2} \mathrm{TiS}_{9}$ complex, it is likely that this reaction proceeds via organosulfur intermediates. The molecular structure of $\left(\mathrm{MeC}_{5} \mathrm{H}_{4}\right)_{2} \mathrm{~V}_{2} \mathrm{~S}_{3}$ consists of equivalent $\left(\mathrm{MeC}_{5} \mathrm{H}_{4}\right) \mathrm{V}$ units bridged by three different types of sulfur ligands (Figure 1). The electronic contribution of these $\mu-\mathrm{S}, \mu, \eta^{1}-\mathrm{S}_{2}$, and $\mu, \eta^{2}-\mathrm{S}_{2}$ ligands results in a total of 30-32 electrons, depending on whether one regards the $\eta^{\prime}-\mathrm{S}_{2}$ ligand as a 2 or 4 electron ligand. Although the molecule is electron deficient, one sulfur atom can be abstracted by $\mathrm{PBu}_{3}$ to give the still more unsaturated complex $\left(\mathrm{C}_{5} \mathrm{H}_{4} \mathrm{R}\right)_{2} \mathrm{~V}_{2} \mathrm{~S}_{4}(\mathrm{R}=\mathrm{Me}$, $\mathrm{i}$-prop), in which the $\mathrm{V}$ atoms are bridged by one $\mu, \eta^{1}-S_{2}$ and two $\mu$-S ligands (Figure 2). ${ }^{8}$ The driving force for this reaction may be the achievement of a closed shell configuration for the metal atoms by $\pi$-interactions of

TABLE I

Ligand assemblies for bis(cyclopentadienyl transition metal) sulfides

\begin{tabular}{|c|c|c|c|}
\hline Compound & $\begin{array}{l}\text { no of } \\
\text { isomers }\end{array}$ & ligand types & \\
\hline $\begin{array}{l}\left(\mathrm{MeC}_{3} \mathrm{H}_{4}\right)_{2} \mathrm{~V}_{2} \mathrm{~S}_{4} \\
\left(\mathrm{i}-\mathrm{prop} \mathrm{C}_{5} \mathrm{H}_{4}\right)_{2} \mathrm{~V}_{2} \mathrm{~S}_{4} \\
\left(\mathrm{MeC}_{5} \mathrm{H}_{4}\right)_{2} \mathrm{~V}_{2} \mathrm{~S}_{3} \\
\left(\mathrm{i}-\mathrm{prop}_{3} \mathrm{C}_{5} \mathrm{H}_{4}\right)_{2} \mathrm{~V}_{2} \mathrm{~S}_{5} \\
\left(\mathrm{C}_{5} \mathrm{H}_{5}\right)_{2} \mathrm{Nb}_{2} \mathrm{~S}_{5} \\
\left(\mathrm{C}_{5} \mathrm{Me}_{5}\right)_{2} \mathrm{Cr}_{2} \mathrm{~S}_{4} \\
\left(\mathrm{C}_{5} \mathrm{Me}_{5}\right)_{2} \mathrm{Cr}_{2} \mathrm{~S}_{5} \\
\left(\mathrm{C}_{5} \mathrm{H}_{5}\right)_{2} \mathrm{Mo}_{2} \mathrm{~S}_{4} \\
\left(\mathrm{MeC}_{5} \mathrm{H}_{4}\right)_{2} \mathrm{Mo}_{2} \mathrm{~S}_{4} \\
\left(\mathrm{C}_{5} \mathrm{Me}_{5}\right)_{2} \mathrm{Mo}_{2} \mathrm{~S}_{4}\end{array}$ & $\begin{array}{l}1 \\
1 \\
1 \\
1 \\
1 \\
1 \\
1 \\
1 \\
1 \\
3\end{array}$ & $\begin{array}{l}\mu-S ; \operatorname{syn}-\mu-\eta^{1}-S_{2} \\
\mu-S ; \operatorname{syn}-\mu-\eta^{1}-S_{2} \\
\mu-S ; \mu-\eta^{2}-S_{2} \\
\mu-S ; \mu-\eta^{2}-S_{2} \\
? \\
\mu-S ; \mu-\eta^{2}-S_{2} \\
\mu-S: \text { iso- } \mu-\eta^{1}-S_{2}: \mu-\eta^{2}-S_{2} \\
\mu-S ; S_{\text {ter }} \\
\mu-S ; S_{\text {ter }} \\
\mu-S ; \mu-\eta^{2}-S_{2} \\
\mu-\eta^{2}-S_{2} ; S_{\text {ter }} \\
\mu-S ; S_{\text {ter }} \\
\mu-\eta^{1}, \eta^{2}-S_{2} ; \text { skew- }-\mu-\eta^{1}-S_{2} ; \eta^{2}-S_{z} \\
\mu-S ; S_{\text {ter }} \\
\mu-\eta^{2}-S_{2} ; S_{\text {ter }} \\
\mu-S ; S_{\text {ter }} \\
? \\
\text { syn- }-\mu-\eta^{1}-S_{2} ; \mu-\eta^{2}-S_{2} \\
\text { syn- }-\mu-\eta^{1}-S_{2} ; \mu-\eta^{2}-S_{2} \\
\mu-\eta^{1}, \eta^{2}-S_{z}\end{array}$ & $\begin{array}{l}(8) \\
(8) \\
(6) \\
(8) \\
(9) \\
(12) \\
(10) \\
(18) \\
(20) \\
(13,20)\end{array}$ \\
\hline
\end{tabular}




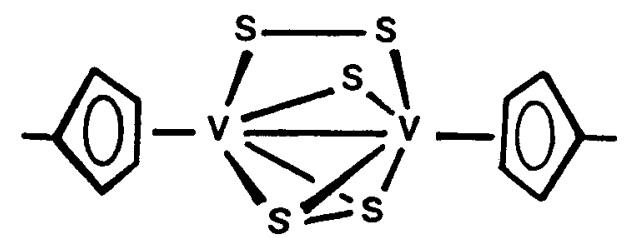

FIGURE 1 Molecular structure of $\left(\mathrm{MeC}_{5} \mathrm{H}_{4}\right)_{2} \mathrm{~V}_{2} \mathrm{~S}_{5}$.

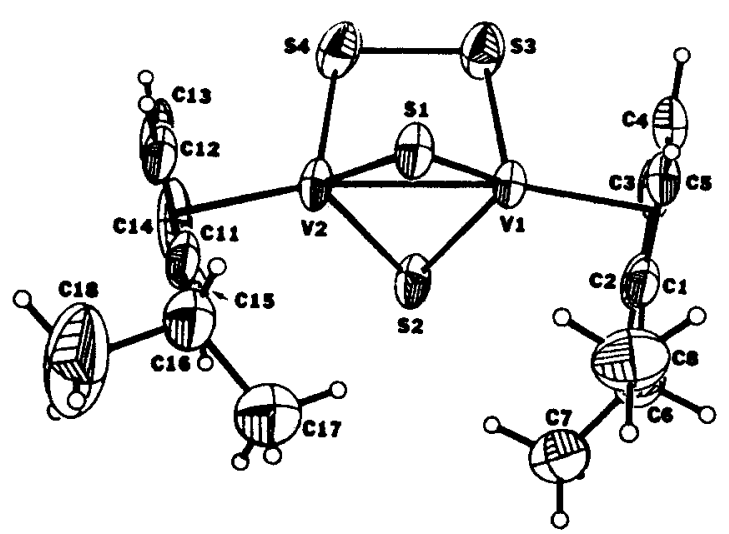

FIGURE 2 ORTEP drawing of (i-propC $\left.\mathrm{C}_{5} \mathrm{H}_{4}\right)_{2} \mathrm{~V}_{2} \mathrm{~S}_{4}$.

all sulfur ligands with the vanadium centers as indicated by very short V-S bonding distances.

$\left(\mathrm{C}_{5} \mathrm{H}_{5}\right)_{2} \mathrm{Nb}_{2} \mathrm{~S}_{5}$, which is formed from $\mathrm{C}_{5} \mathrm{H}_{5} \mathrm{Nb}(\mathrm{CO})_{3}$ THF and $\mathrm{S}_{8},{ }^{9}$ might have a structure closely related to $\left(\mathrm{C}_{5} \mathrm{H}_{4} \mathrm{R}\right)_{2} \mathrm{~V}_{2} \mathrm{~S}_{5}{ }^{8}$ The desulfurization of $\mathrm{H}_{2} \mathrm{~S}$ or $\mathrm{CH}_{3} \mathrm{SH}$, respectively, by $\mathrm{C}_{5} \mathrm{H}_{5} \mathrm{Nb}(\mathrm{CO})_{3} \mathrm{THF}$ only leads to $\left[\mathrm{C}_{5} \mathrm{H}_{5} \mathrm{Nb}(\mathrm{CO})_{2}\right]_{2}-(\mu-\mathrm{S})_{2}$ and $\left[\mathrm{C}_{5} \mathrm{H}_{5} \mathrm{Nb}(\mathrm{CO})_{2}\right]_{2}(\mu-\mathrm{S})_{3}{ }^{9}$

\subsection{The Chromium Triad}

For the preparation of sulfur rich chromium cyclopentadienides the M-M triply bonded $\left[\mathrm{C}_{5} \mathrm{Me} \mathrm{e}_{5} \mathrm{Cr}(\mathrm{CO})_{2}\right]_{2}$ seems to be the only suitable substrate. Apparently, the methyl substituents at the cyclopentadienyl ligand favor the reaction, for $\left[\mathrm{C}_{5} \mathrm{H} \mathrm{H}_{5} \mathrm{Cr}(\mathrm{CO})_{2}\right]_{2}$ does not react at all. ${ }^{10}$ By contrast, the reaction of $\left[\mathrm{C}_{5} \mathrm{H}_{5} \mathrm{Cr}(\mathrm{CO})_{3}\right]_{2}$ with $\mathrm{S}_{8}$ results in the insertion of a mono- or disulfur ligand into the relatively labile $\mathrm{Cr}-\mathrm{Cr}$ bond.${ }^{11}$ Complete $\mathrm{CO}$-substitution was not observed in this reaction.

The molecular structure of $\left(\mathrm{C}_{5} \mathrm{Me}_{5}\right)_{2} \mathrm{Cr}_{2} \mathrm{~S}_{5}$ (Figure 3) contains a $\mu$-S-, a $\mu, \eta^{2}-\mathrm{S}_{2}-$, and a $\mu\left(\eta^{1}-S_{2}\right)$ ligand, the latter representing a novel type of disulfur bridge in which only one sulfur atom is coordinated to both $\mathrm{Cr}$ atoms, whereas the other $\mathrm{S}$ atom is uncoordinated. ${ }^{10}$ The unique nature of this ligand is further documented by Cr-S-S angles of about $109^{\circ}$, corresponding to $\mathrm{sp}^{3}$ hybridization, and a rather long $\mathrm{S}$-S bond length of $2.10 \AA$ when compared to other $\mu, \eta^{2}-S_{2}$ ligands. A still longer S-S distance $(2.15 \AA)$ is found for the $\eta^{2}-S_{2}$ ligand. These findings suggest, in particular for the $\eta^{2}-S_{2}$ ligand, a back donation from occupied metal-d-orbitals into vacant $\pi^{*}$ orbitals of the $S_{2}$ ligands. This explanation would be in contrast to the expectation that transition metal atoms in a low d configuration prefer stabilization by disulfur ligand orbitals. ${ }^{2}$ 

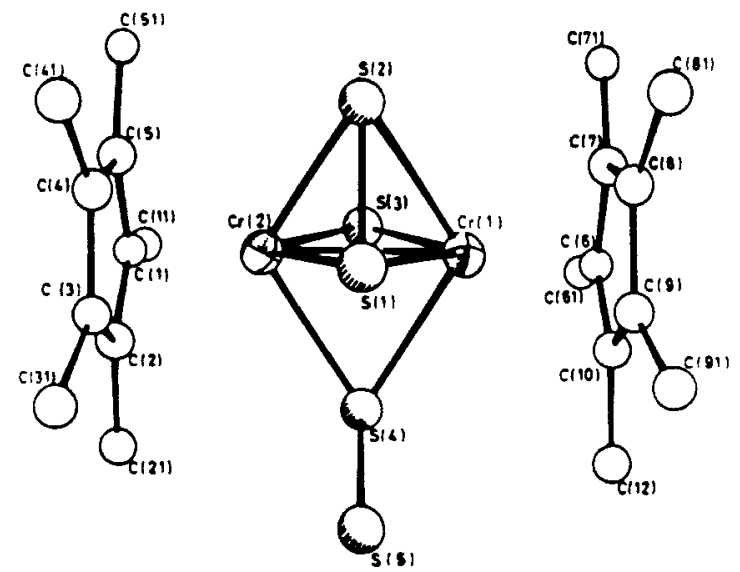

FIGURE 3 View of $\left(\mathrm{C}_{5} \mathrm{Me}_{5}\right)_{2} \mathrm{Cr}_{2} \mathrm{~S}_{3}$.

$\left(\mathrm{C}_{5} \mathrm{Me}_{5}\right)_{2} \mathrm{Cr}_{2} \mathrm{~S}_{5}$ can easily be transferred into $\left(\mathrm{C}_{5} \mathrm{Me}_{5}\right)_{2} \mathrm{Cr}_{2} \mathrm{~S}_{4}$ by abstraction of the uncoordinated sulfur atom of the $\eta^{1}-\mathrm{S}_{2}$ ligand by means of $\mathrm{PPh}_{3}{ }^{12}$ The latter complex should have a structure similar to $\left(\mathrm{C}_{5} \mathrm{Me}_{5}\right)_{2} \mathrm{Mo}_{2}\left(\mu-\mathrm{S}_{2}\right)-(\mu-\mathrm{S})_{2}{ }^{13}$ as suggested by spectral data.

Two methods have been developed to transfer the insoluble polymer $\left[\left(\mathrm{C}_{5} \mathrm{H}_{5}\right)_{2} \mathrm{Mo}_{2} \mathrm{~S}_{\mathrm{x}}\right]_{\mathrm{n}}$, which results from the reaction of $\mathrm{S}_{8}$ with $\left[\mathrm{C}_{5} \mathrm{H}_{5} \mathrm{Mo}(\mathrm{CO})_{3}\right]_{2}{ }^{4}$ and $\left[\mathrm{C}_{5} \mathrm{H}_{5} \mathrm{Mo}(\mathrm{CO})_{2}\right]_{2},{ }^{14}$ respectively, into the soluble complex $\left(\mathrm{C}_{5} \mathrm{H}_{5}\right)_{2} \mathrm{Mo}_{2}-(\mu-\mathrm{S})_{2}(\mu-\mathrm{SH})_{2}$; the hydrosulfido complex is either formed by hydrogenation with $\mathrm{H}_{2}$ under mild conditions ${ }^{15}$ or by reduction with $\mathrm{LiEt}_{3} \mathrm{BH}^{16}$ In this complex two isomers exist showing a relatively slow cis-trans isomerization. ${ }^{17}$

The mononuclear hydrosulfido complexes $\mathrm{C}_{5} \mathrm{H}_{5} \mathrm{M}(\mathrm{CO})_{3} \mathrm{SH}(\mathrm{M}=\mathrm{Mo}, \mathrm{W})$ are formed from the reaction of $\mathrm{C}_{5} \mathrm{H}_{5} \mathrm{M}(\mathrm{CO})_{3} \mathrm{H}$ with methylthiirane; they give the carbonyl free dinuclear compounds $\left(\mathrm{C}_{5} \mathrm{H}_{3}\right)_{2} \mathrm{M}_{2} \mathrm{~S}_{4}$ on thermal decomposition. ${ }^{18}$ An excess of methylthiirane leads to the bis-dithiolato complex $\left(\mathrm{C}_{5} \mathrm{H}_{5}\right)_{2}-\left(\mu-\mathrm{SCH}_{2} \mathrm{CHMeS}\right)$, which releases the olefin part at elevated temperatures. ${ }^{19}\left(\mathrm{MeC}_{5} \mathrm{H}_{4}\right)_{2} \mathrm{Mo}_{2} \mathrm{~S}_{4}$ is formed in low yields from $\left[\mathrm{MeC}_{5} \mathrm{H}_{4} \mathrm{Mo}(\mathrm{CO})_{3}\right]_{2}$ and $\mathrm{S}_{8}{ }^{20}$

Scheme 2. Possible Isomers in the $\left(\mathrm{C}_{5} \mathrm{Me}_{5}\right)_{2} \mathrm{Mo}_{2} \mathrm{~S}_{4}-$ System

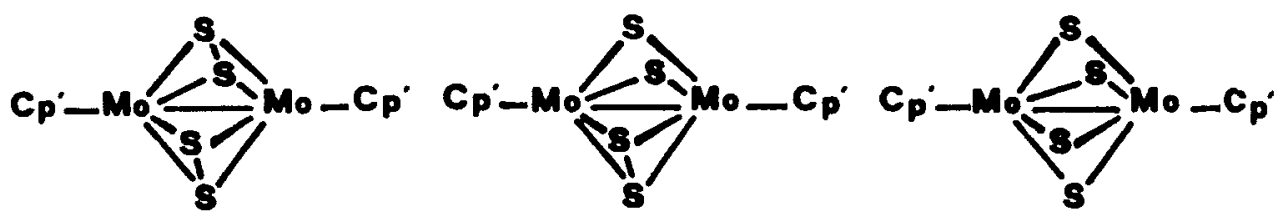

A

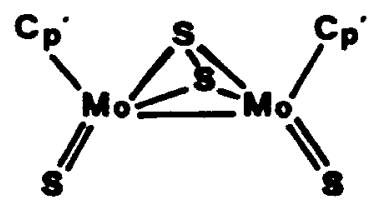

B

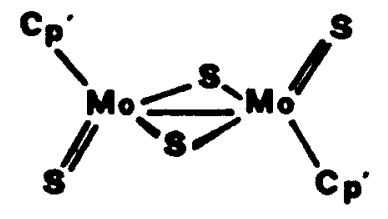

C 
BIS(CYCLOPENTADIENYL TRANSITION METAL)

223

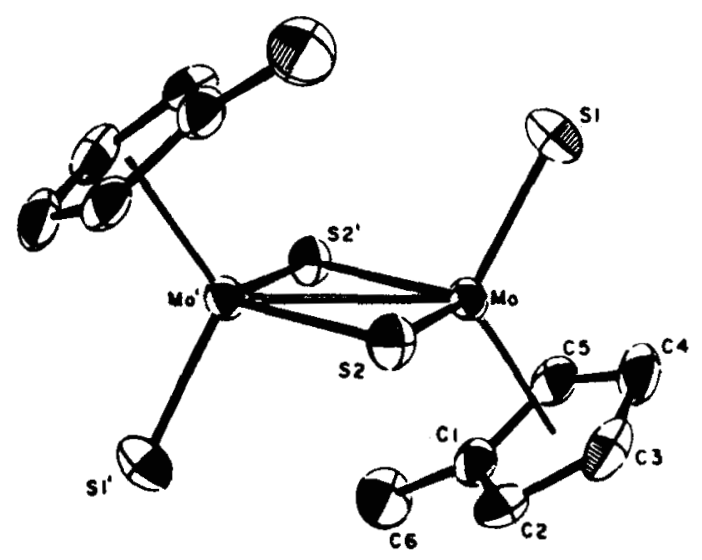

FIGURE 4 ORTEP drawing of $\left(\mathrm{MeC}_{5} \mathrm{H}_{4}\right)_{2} \mathrm{Mo}_{2}(\mu-\mathrm{S})_{2} \mathrm{~S}_{2}$.

Much better yields of soluble compounds can be obtained when starting from the permethylated complex $\mathrm{C}_{5} \mathrm{Me}_{5} \mathrm{Mo}(\mathrm{CO})_{3} \mathrm{H}$ and $\mathrm{S}_{8}$ : In boiling $\mathrm{THF}\left(\mathrm{C}_{5} \mathrm{Me}_{5}\right)_{2} \mathrm{Mo}_{2} \mathrm{~S}_{4}$ can be isolated along with $\left(\mathrm{C}_{5} \mathrm{Me}_{5}\right)_{2} \mathrm{Mo}_{2} \mathrm{~S}_{10}$ as a byproduct. ${ }^{20}$ The structures of the three $\mathrm{Cp}_{2} \mathrm{Mo}_{2} \mathrm{~S}_{4}$ compounds mentioned above all belong to the same type $\mathrm{C}$ (Scheme 2), ${ }^{18,20}$ As shown for $\left(\mathrm{MeC}_{5} \mathrm{H}_{4}\right)_{2} \mathrm{Mo}_{2} \mathrm{~S}_{4}$ in Figure 4 they are characterized by a planar $\mathrm{Mo}_{2}(\mu-\mathrm{S})_{2}$ unit, to which terminal sulfide ligands are attached in an anti configuration, leaving the $\mathrm{Mo}(\mathrm{V})$ centers in an electron deficient situation. $\left(\mathrm{C}_{5} \mathrm{Me}_{5}\right)_{2} \mathrm{Mo}_{2} \mathrm{~S}_{10}$ contains three types of $S_{2}$ ligands (Figure 5), involving the rather rare example of a non-planar $\eta^{1}-S_{2}$ bridge. This compound is easily desulfurize by $\mathrm{H}_{2}$ with the formation of $\mathrm{H}_{2} \mathrm{~S}$ and $\left(\mathrm{C}_{5} \mathrm{Me}_{5}\right)_{2} \mathrm{MO}_{2}(\mu-\mathrm{S})_{2}(\mu-\mathrm{SH})_{2}{ }^{15}$

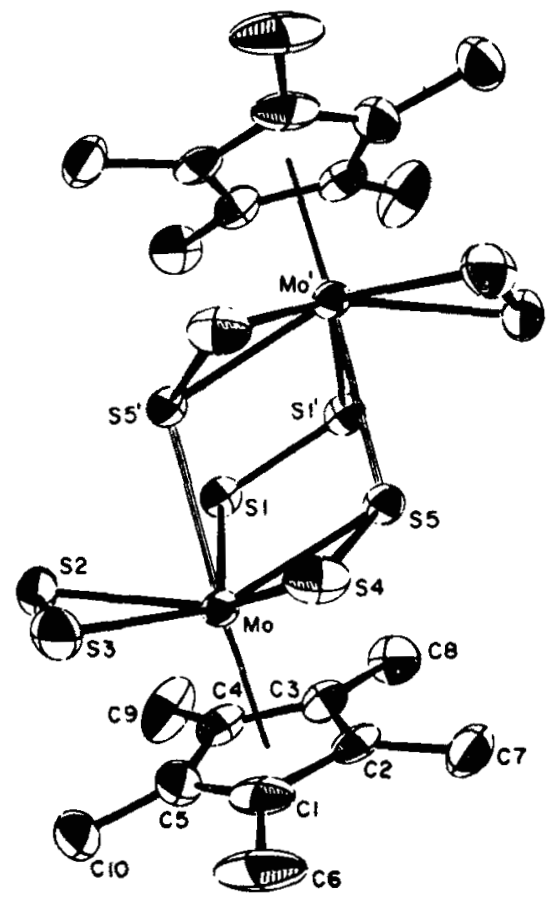

FIGURE 5 Perspective drawing of $\left(\mathrm{C}_{3} \mathrm{Me}_{5}\right)_{2} \mathrm{Mo}_{2} \mathrm{~S}_{105}$. 


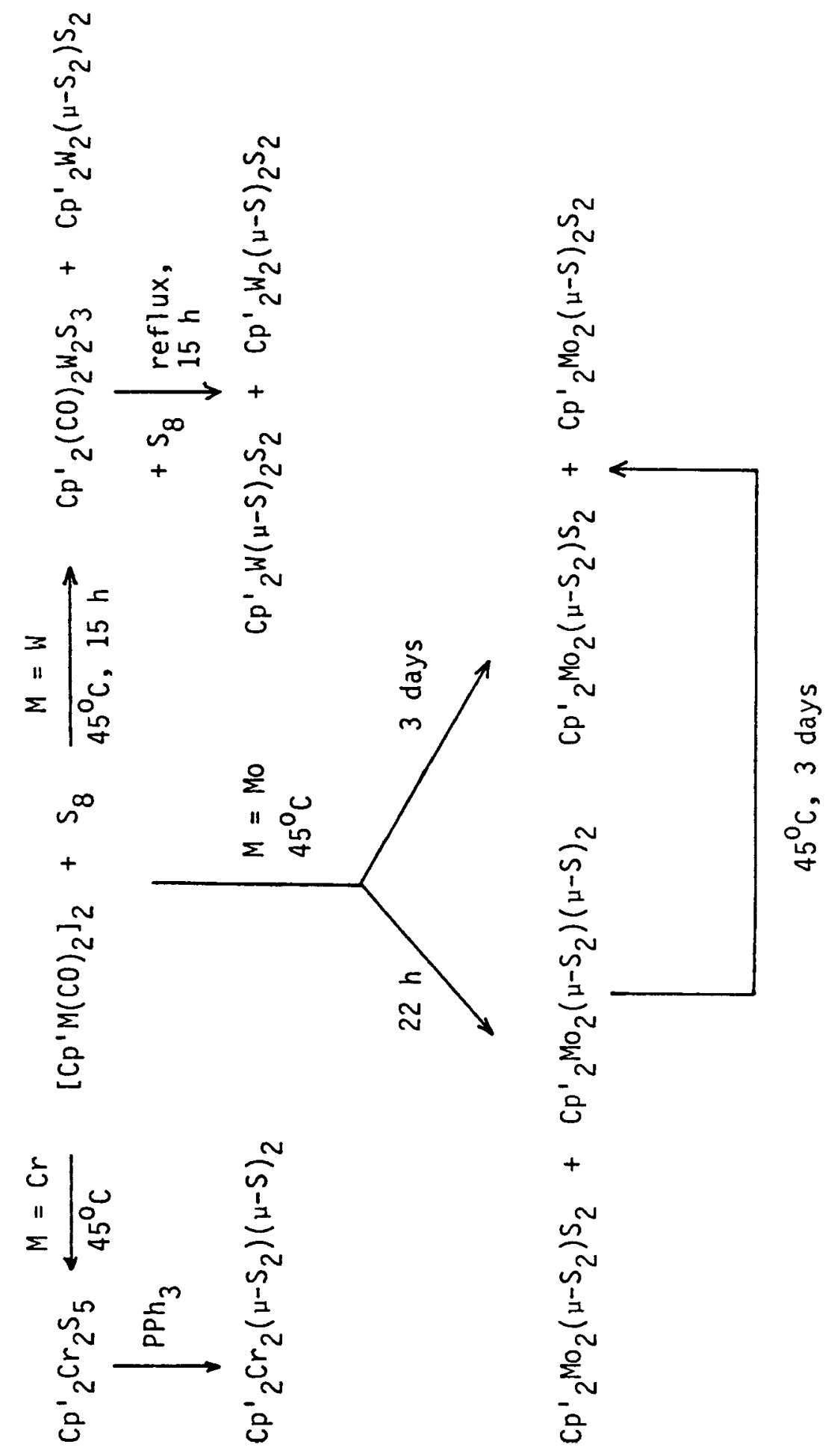


Replacement of the $\mathrm{Cp}$ ring in $\mathrm{CpMo}(\mathrm{CO})_{3} \mathrm{H}$ by the isoelectronic trispyrazolylborato group drastically changes the reactivity, for the reaction with $\mathrm{S}_{8}$ stops at $\left[\mathrm{HBpz}_{3} \mathrm{Mo}(\mathrm{CO})_{2}\right]_{2} \mathrm{~S}$, which is characterized by a linear $\mathrm{Mo} \equiv \mathrm{S} \equiv \mathrm{Mo}$ unit. ${ }^{21}$

The high reactivity of the metal-metal triple bond in $\left[\mathrm{CpMo}(\mathrm{CO})_{2}\right]_{2}$ derivatives can also be used for the incorporation of sulfur, but with different results depending on the nature of the $\mathrm{Cp}$ ring. Thus, $\left[\mathrm{C}_{5} \mathrm{H}_{5} \mathrm{Mo}(\mathrm{CO})_{2}\right]_{2}$ reacts with $\mathrm{S}_{8}(1: 1$ molar ratio) with formation of the trimolybdenum cluster $\left[\left(\mathrm{C}_{5} \mathrm{H}_{5}\right)_{3} \mathrm{Mo}_{3}-(\mathrm{CO})_{6}\left(\mu_{3}-\mathrm{S}\right)\right]\left[\mathrm{C}_{5} \mathrm{H}_{5} \mathrm{Mo}(\mathrm{CO})_{3}{ }^{14}\right.$ In the $\left(\mathrm{C}_{5} \mathrm{H}_{5}\right)_{3} \mathrm{Mo}_{3}(\mathrm{CO})_{6} \mathrm{~S}$ cation of this cluster the trigonal plane of three $\mathrm{C}_{5} \mathrm{H}_{5}(\mathrm{CO})_{2} \mathrm{Mo}-$ units is capped by a $\mu_{3}-\mathrm{S}$ atom.

These results are in contrast to the reaction behavior of $\left[\mathrm{C}_{5} \mathrm{Me}_{5} \mathrm{Mo}(\mathrm{CO})_{2}\right]_{2}$, which gives with elemental sulfur three different isomers A-C (Scheme 2) of the general formula $\left(\mathrm{C}_{5} \mathrm{Me}_{5}\right)_{2} \mathrm{Mo}_{2} \mathrm{~S}_{4}$, no stable $\mathrm{CO}$ containing complex could be obtained. ${ }^{13}$ It has been shown that the isomer ratio depends on the reaction conditions. Thus, isomer $A$ is less stable and can thermally be converted into B and C (Scheme 3) ${ }^{13}$ whereas preliminary photochemical investigations have shown that irradiation of any isomer eventually yields the other two isomers. ${ }^{22}$ The molecular structure of A resembles that one of the above mentioned $\left(\mathrm{C}_{5} \mathrm{Me}_{5}\right)_{2} \mathrm{Cr}_{2} \mathrm{~S}_{5}$ (Figure 3 ) with the only exception that the $\eta^{1}(\mu-S, S)$ ligand is replaced by a mono-sulfur bridge. ${ }^{13}$ Further structural possibilities especially for Mo(V) dimers have been discussed elsewhere. ${ }^{20,23}$

Although the W-S-W bridged compound $\left[\mathrm{C}_{5} \mathrm{H}_{5}(\mathrm{CO})_{3} \mathrm{~W}\right]_{2} \mathrm{~S}$ has already been prepared from $\mathrm{C}_{5} \mathrm{H}_{5} \mathrm{~W}(\mathrm{CO})_{3} \mathrm{H}$ and $\mathrm{S}\left(\mathrm{NMe}_{2}\right)_{2}{ }^{24}$ or $\mathrm{SO}_{2},{ }^{25}$ the W-W bond of $\left[\mathrm{CpW}(\mathrm{CO})_{3}\right]_{2}$ $\left(\mathrm{Cp}=\mathrm{C}_{5} \mathrm{H}_{5}\right.$ or $\left.\mathrm{C}_{5} \mathrm{Me}_{5}\right)$ is inert towards the insertion of sulfur. On the other hand, $\left[\mathrm{C}_{5} \mathrm{Me}_{5} \mathrm{~W}(\mathrm{CO})_{2}\right]_{2}$ reacts with $\mathrm{S}_{8}$ with formation of a stable carbonyl-containing complex along with two $\left(\mathrm{C}_{5} \mathrm{Me}_{5}\right)_{2} \mathrm{~W}_{2} \mathrm{~S}_{4}$ isomers. ${ }^{13}\left(\mathrm{C}_{5} \mathrm{Me}_{5}\right)_{2}(\mathrm{CO})_{2} \mathrm{~W}_{2} \mathrm{~S}_{3}$ consists of a planar $\mathrm{W}_{2}(\mu-\mathrm{S})_{2}$ core which is polarized by the coordination of two terminal CO groups to one $\mathrm{W}$ atom and of one terminal S ligand to the other W atom (Figure 6). Both CO groups can be replaced by sulfur, leading to two isomers of $\left(\mathrm{C}_{5} \mathrm{Me}_{5}\right)_{2} \mathrm{~W}_{2} \mathrm{~S}_{4}$ which are related to the corresponding Mo isomers $\mathrm{B}$ and $\mathrm{C}^{13}$

An increased reactivity has been found for condensed sulfur vapor, allowing the access to thermally unstable, still $\mathrm{CO}$ containing products. ${ }^{26}$ However, this stepwise oxidation of the metal-metal triple bond of $\left[\mathrm{C}_{5} \mathrm{Me}_{3} \mathrm{M}(\mathrm{CO})_{2}\right]_{2}(\mathrm{M}=\mathrm{Mo}$, W) ends up in each case in the formation of the thermally more stable $\left(\mathrm{C}_{5} \mathrm{Me}_{5}\right)_{2} \mathrm{M}_{2} \mathrm{~S}_{4}$ complexes.

The different results obtained from the $\left[\mathrm{C}_{5} \mathrm{Me}_{5} \mathrm{M}(\mathrm{CO})_{2}\right]_{2}$ series $(\mathbf{M}=\mathrm{Cr}, \mathrm{Mo}, \mathrm{W})$ are summarized in Scheme 3 and may be in part explained by differences in the reactivity of the metal-metal triple bond. ${ }^{27}$ Thus, it is known that $\left[\mathrm{C}_{5} \mathrm{Me} \mathrm{e}_{5} \mathrm{Cr}(\mathrm{CO})_{2}\right]_{2}$ is much less reactive than its Mo and $\mathrm{W}$ homologues. On the other hand, it is not yet clear why the coordination of a $\eta^{1}(\mu-\mathrm{S}, \mathrm{S})$ disulfur ligand is preferred to a simple, electronically

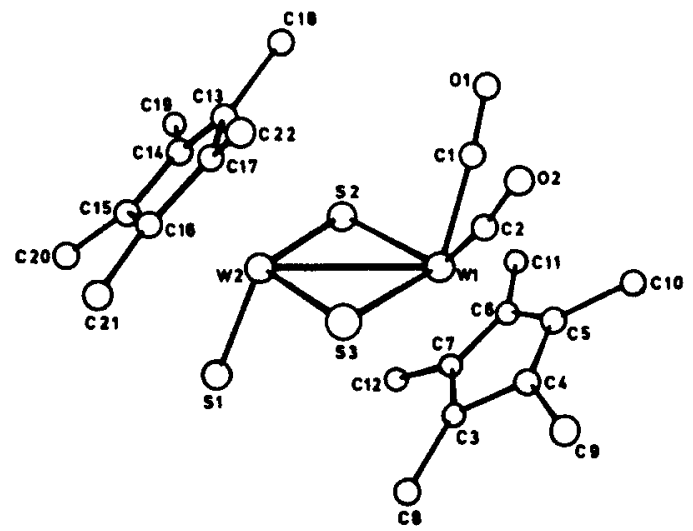

FIGURE 6 Molecular structure of $\left(\mathrm{C}_{3} \mathrm{Me}_{3}\right)_{2} \mathrm{~W}_{2}(\mathrm{CO})_{2} \mathrm{~S}_{3}$. 
equivalent $\mu$-S ligand in $\left(\mathrm{C}_{5} \mathrm{Me}_{5}\right)_{2} \mathrm{Cr}_{2} \mathrm{~S}_{5}$, whereas in the Mo or $\mathrm{W}$ case only "conventional" mono- and disulfur ligands exist.

\subsection{Manganese and Rhenium Sulfides}

No sulfur rich $\mathrm{Mn}$ and $\mathrm{Re}$ cyclopentadienides are known so far. The incorporation of elemental sulfur into $\mathrm{Cp}(\mathrm{CO})_{2} \mathrm{M}$ (solv) complexes $(\mathrm{M}=\mathrm{Mn}$, Re; solv $=$ THF or ether) does not lead to a complete $\mathrm{CO}$ substitution. Instead, a series of interesting $\mathrm{CO}$ containing compounds with different assemblies of mono-, di-, or trisulfur ligands can be isolated. ${ }^{28}$ We found the reaction of $\left(\mathrm{C}_{5} \mathrm{Me}_{5}\right)_{2} \mathrm{Mn}$ with $\mathrm{S}_{8}$ to be a promising entry to dimeric sulfides. A green and a blue isomer of formula $\left(\mathrm{C}_{5} \mathrm{Me}_{5}\right)_{2} \mathrm{Mn}_{2} \mathrm{~S}_{4}$ could be isolated, but their structures are still unknown. ${ }^{29}$

\subsection{Iron and Cobalt Sulfides}

The only hitherto employed cyclopentadienyl iron substrate is $\left[\mathrm{CpFe}(\mathrm{CO})_{2}\right]_{2}$, which in the case of $\mathrm{Cp}=\mathrm{C}_{5} \mathrm{H}_{5}$ reacts with $\mathrm{S}_{8}$ in boiling toluene with formation of the cubane-like cluster $\left(\mathrm{C}_{5} \mathrm{H}_{5}\right)_{4} \mathrm{Fe}_{4} \mathrm{~S}_{4}{ }^{4,30}$ As an intermediate in this reaction the polysulfur bridged complex $\left[\mathrm{C}_{5} \mathrm{H}_{5} \mathrm{Fe}(\mathrm{CO})_{2}\right]_{2}\left(\mu-\mathrm{S}_{3}\right)$ was established, which is formed in boiling THF and which can be decarbonylated at elevated temperatures. ${ }^{31}$ By contrast, the photolytic reaction of $\left[\mathrm{C}_{5} \mathrm{H}_{5} \mathrm{Fe}(\mathrm{CO})_{2}\right]_{2}$ with $\mathrm{S}_{8}$ gives $\left(\mathrm{C}_{5} \mathrm{H}_{5}\right)_{2} \mathrm{Fe}_{2}(\mathrm{CO}) \mathrm{S}_{4}$ which can be converted into two isomers of formula $\left(\mathrm{C}_{5} \mathrm{H}_{5}\right)_{2} \mathrm{Fe}_{2} \mathrm{~S}_{4}$ by further irradiation. ${ }^{32}$ The structure of one of these isomers is characterized by symmetrically bridging $\eta^{1}-S_{2}$ and $\eta^{2}-S_{2}$ ligands being perpendicularly oriented to each other. ${ }^{33}$

Only one isomer is formed in a good yield in the reaction of $\left[\mathrm{C}_{5} \mathrm{Me}_{5}(\mathrm{CO})_{2} \mathrm{Fe}\right]_{2}$ with an excess of sulfur in boiling toluene. ${ }^{34}\left(\mathrm{C}_{5} \mathrm{Me}_{5}\right)_{2} \mathrm{Fe}_{2} \mathrm{~S}_{4}$ has the same structure as the unsubstituted compound. Both compounds are distinguished by short $\mathrm{S}-\mathrm{S}$ distances, e.g. $2.01 \AA$ near the average for the $\eta^{1}-\mathrm{S}_{2}$ ligand. ${ }^{33,34} \mathrm{~A}$ relatively long $\mathrm{Fe}-\mathrm{Fe}$ distance (ca. $3.50 \AA$ ) outside the range of metal-metal interaction may be indicative of enhanced donor electronic activities of the $\boldsymbol{\eta}^{1}-\mathrm{S}_{2}$ ligand, so that it can be regarded as a 4 rather than a 2 electron ligand. A similar situation has been found in $\left(\mathrm{C}_{5} \mathrm{H}_{3}\right)_{2} \mathrm{Fe}_{2}\left(\eta^{1}-\mathrm{S}_{2}\right)$ $(\mu-\mathrm{SR})_{2} \cdot{ }^{35}$

Although the tendency of the $\mathrm{C}_{5} \mathrm{H}_{5} \mathrm{Co}$-fragment to form sulfide clusters is well established with the clusters $\left(\mathrm{C}_{5} \mathrm{H}_{5}\right)_{3} \mathrm{Co}_{3} \mathrm{~S}_{2}{ }^{36}$ and $\left(\mathrm{C}_{5} \mathrm{H}_{5}\right)_{4} \mathrm{Co}_{4} \mathrm{~S}_{4},{ }^{37}$ the first dinuclear compound was discovered only very recently. $\left(\mathrm{C}_{5} \mathrm{Me}_{5}\right)_{2} \mathrm{Co}_{2} \mathrm{~S}_{4}$ is synthesized from $\left[\mathrm{C}_{5} \mathrm{Me}_{5} \mathrm{Co}(\mathrm{CO})\right]_{2}$ and sulfur under mild conditions. ${ }^{34} \mathrm{It}$ represents a new structural type,

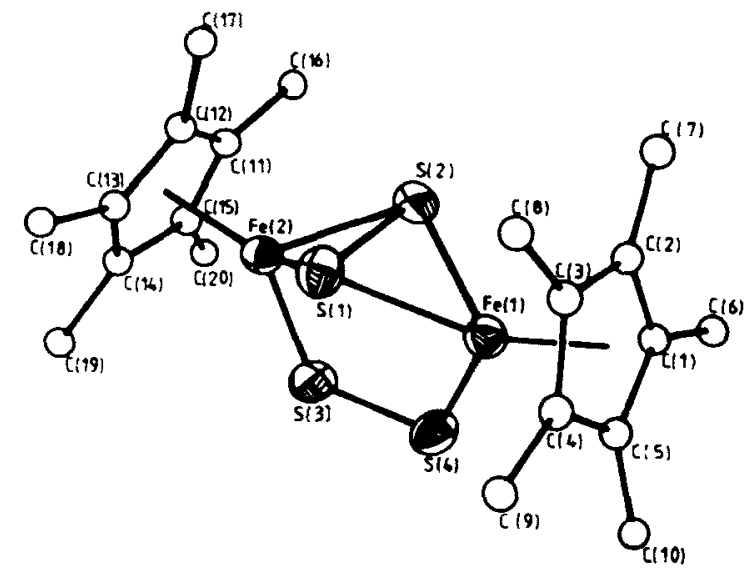

FIGURE 7 ORTEP drawing of $\left(\mathrm{C}_{5} \mathrm{Me}_{5}\right)_{2} \mathrm{Fe}_{2} \mathrm{~S}_{4}$ 


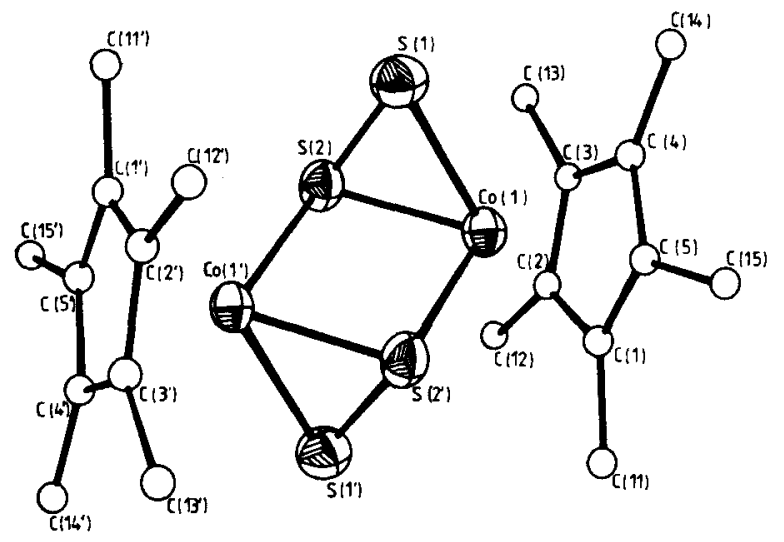

FIGURE 8 View of $\left(\mathrm{C}_{3} \mathrm{Me}_{5}\right)_{2} \mathrm{Co}_{2} \mathrm{~S}_{4}$.

although it contains two already known $\eta^{1}, \eta^{2}$-disulfur bridges, contributing four electrons to each metal atom (Figure 8). Characteristic of the molecule is a $\mathrm{Co}_{2} \mathrm{~S}_{2}$ plane, one further S-atom is located above and the other one below this plane. The Co-Co distance of $3.38 \AA$, precluding any metal-metal interaction, is in agreement with the diamagnetic character of the molecule.

\section{REACTIONS}

\subsection{Sulfur Ligand Transformations}

Sulfur ligand transformations are often combined with changes in the oxidation state of the metal center. An intramolecular redox process, which is symbolized by the equation $2 \mathrm{~S}^{2-}+2 \mathrm{Mo}(\mathrm{V}) \leftrightharpoons \mathrm{S}_{2}^{2-}+2 \mathrm{Mo}(\mathrm{IV})$ may be responsible for the interconversion of the Mo and W isomers A-C (Scheme 2). Additionally, such isomerizations involve the transformation of a monosulfur bridge into a terminal ligand or vice versa dependent on the reaction conditions. ${ }^{13,22}$

The electron deficient complex $\mathrm{Cp}_{2} \mathrm{~V}_{2} \mathrm{~S}_{4}$ (Figure 2) represents a system of particular interest: Electrophilic diazenes promote the oxidative coupling of two $\mathrm{S}^{2-}$ ligands into a $\eta^{2}$-disulfide bridge, when the triazoline ligand acts as a bridge itself ${ }^{38}$ This example further demonstrates that the reactivity of transition metal sulfides needs not be localized exclusively on the sulfur ligands but may also incorporate the metal as a center of reactivity. In order to compensate for the electron deficient character of the metal center a "rotation" of the $\mu, \eta^{1}-S_{2}$ ligand into a $\eta^{2}-S_{2}$ bridge takes place. ${ }^{38} \mathrm{~A}$ similar process also occurs in the addition of $\mathrm{Fe}(\mathrm{CO})_{3}$ - or $\mathrm{Fe}(\mathrm{NO})_{2}$-fragments to $\mathrm{Cp}_{2} \mathrm{~V}_{2} \mathrm{~S}_{4},{ }^{39,40}$ thus allowing the resulting trinuclear clusters to obey the EAN rule (Equation 1).
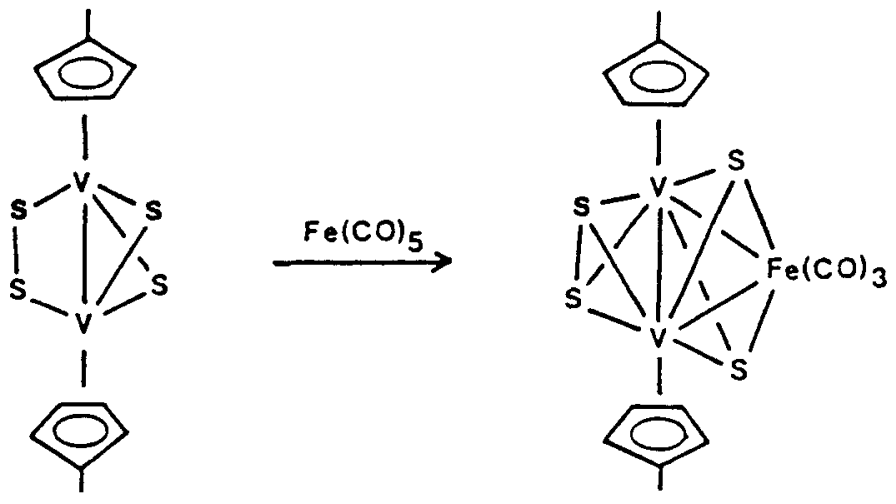
No isomerization reactions have been detected for the chromium compounds $\left(\mathrm{C}_{5} \mathrm{Me}_{5}\right)_{2} \mathrm{Cr}_{2} \mathrm{~S}_{4}$ and $\left(\mathrm{C}_{5} \mathrm{Me}_{5}\right)_{2} \mathrm{Cr}_{2} \mathrm{~S}_{5}$, but they react under $\mathrm{H}_{2}$ pressure with formation of the cubane-like cluster $\left(\mathrm{C}_{5} \mathrm{Me}_{5}\right)_{4} \mathrm{Cr}_{4} \mathrm{~S}_{4} \cdot{ }^{12} \mathrm{~A}$ mechanism for this reaction has not yet been established, but it is very likely, that the presence of $\mathrm{H}_{2}$ is essential for this reaction. In this regard it may be of interest that $\left(\mathrm{C}_{5} \mathrm{Me}_{5}\right)_{2} \mathrm{Fe}_{2} \mathrm{~S}_{4}$ is obviously inert towards $\mathrm{H}_{2}$, even at a pressure of 250 bar. $^{34}$

A rearrangement of terminal into bridging sulfide ligands is facilitated by hydrogen or unsaturated organic molecules. ${ }^{20}$ However, the formation of $\left(\mathrm{C}_{5} \mathrm{Me}_{5}\right)_{2} \mathrm{Mo}_{2}(\mu-\mathrm{SH})_{2}(\mu-\mathrm{S})_{2}$ is also possible upon insertion of hydrogen into the $\eta^{2}$-disulfur bridge of the Mo(IV) isomer A (Scheme 2) ${ }^{12}$ This observation suggests that apart from redox reactions homolytic cleavage of the $\mathrm{S}-\mathrm{S}$ bond may be involved in such processes. A similar bridge cleavage is part of a catalytic cycle in which $\mathrm{SO}_{2}$ is reduced by $\left(\mathrm{C}_{5} \mathrm{Me}_{5}\right)_{2} \mathrm{Mo}_{2}(\mathrm{SH})_{2} \mathrm{~S}_{2}$ to give sulfur and water under mild conditions. ${ }^{41}$

An opening of the "closed" isomer A into the "open" isomers B and C can be observed on exposure of $\left(\mathrm{C}_{5} \mathrm{Me}_{5}\right)_{2} \mathrm{Mo}_{2} \mathrm{~S}_{4}$ to air. ${ }^{13}$ This reaction is accompanied by the substitution of one or two terminal sulfur ligands by oxygen (Scheme 4). The progress of such an oxidation reaction can easily be monitored by ${ }^{95} \mathrm{Mo} \mathrm{nmr}$ spectroscopy, for the chemical shifts are very sensitive to the sulfur to oxygen ratio in the coordination sphere of the metal atom. ${ }^{42}$ It has also been shown that $\left(\mathrm{C}_{5} \mathrm{Me}_{5}\right)_{2} \mathrm{Mo}_{2}(\mu-\mathrm{S})_{2} \mathrm{~S}_{2}$ can be transferred to $\left(\mathrm{C}_{5} \mathrm{Me}_{5}\right)_{2} \mathrm{Mo}_{2}(\mu-\mathrm{S})_{2} \mathrm{O}_{2}$ on exposure to air. ${ }^{20}$ The structure of this compound is analogous to $\left(\mathrm{C}_{5} \mathrm{H}_{5}\right)_{2} \mathrm{Mo}_{2}(\mu-\mathrm{S})_{2} \mathrm{O}_{2}$, which was the first example of an organometallic compound containing doubly briding $\mathrm{S}$ atoms between two transition metal atoms. $^{43}$

The interaction of oxygen with $\mathrm{Cp}_{2} \mathrm{M}_{2} \mathrm{~S}_{4}$-complexes has only been investigated for the Mo derivatives, in which the metal center seems to be the only reaction site. However, several examples have been provided recently in which $\mu-\mathrm{S}$ - as well as $\eta^{2}-\mathrm{S}_{2}$ ligands have been oxidized to $\mu-\mathrm{SO}-{ }^{44,45} \eta^{2}-\mathrm{S}_{2} \mathrm{O}-,{ }^{45,46}$ and $\eta^{2}-\mathrm{S}_{2} \mathrm{O}_{2}-{ }^{45}$ ligands. These results should encourage the quest for new mixed chalcogen ligands in cyclopen-

Scheme 4. Oxidation of $\left(\mathrm{C}_{3} \mathrm{Me}_{5}\right)_{2} \mathrm{Mo}_{2} \mathrm{~S}_{4}$ by air $\left(\delta{ }^{95} \mathrm{Mo}\right.$ values in parentheses)

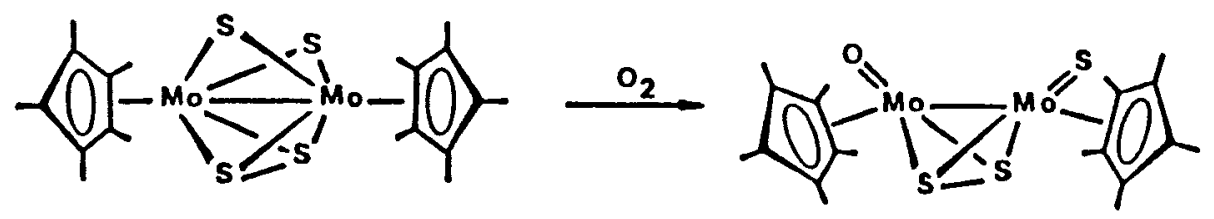

(440)

$(-54,699)$

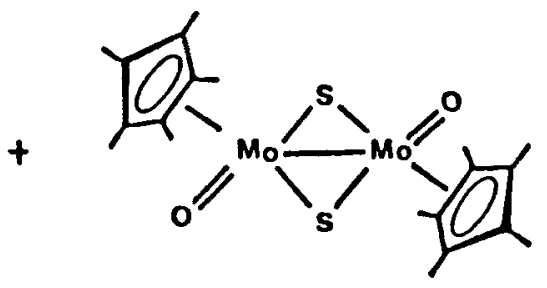

$(-93)$ 
tadienyl complexes. In the same sense the stabilization of Lewis acids by basic sulfide bridges should be possible. As a first example a bis-SO ${ }_{2}$-adduct of $\left[\mathrm{C}_{5} \mathrm{Me}_{5} \mathrm{~W}(\mathrm{CO})_{2}\right]_{2}[\mu$ $\mathrm{S}]_{2}$ has been characterized. ${ }^{25}$

\subsection{Reactions with Organic Molecules}

As established by the results of the crystallographic studies the sulfur ligands may be expected to have a more or less nucleophilic character. Thus, they react with $\mathrm{CF}_{3} \mathrm{CO}_{2} \mathrm{H}$ or $\mathrm{CH}_{3} \mathrm{I}$ and electrophilic alkynes or alkines. For the ligand set present in $\left(\mathrm{C}_{5} \mathrm{Me}_{5}\right)_{2} \mathrm{Cr}_{2} \mathrm{~S}_{5}$ and $\left(\mathrm{C}_{5} \mathrm{Me}_{5}\right)_{2} \mathrm{Mo}_{2} \mathrm{~S}_{4}$ a decrease in nucleophilicity in the order $\eta^{1}-(\mu$-S,S $)$ $>\mu-\mathrm{S}>\left(\eta^{2}-\mathrm{S}_{2}\right)$ has been found. ${ }^{12}$

Different results are obtained when $\mathrm{Cp}_{2} \mathrm{M}_{2} \mathrm{~S}_{\mathrm{x}}(\mathrm{x}=4,5)$ complexes react with electrophilic acetylenes. A mononuclear bischelate complex, $\left(\mathrm{MeC}_{5} \mathrm{H}_{4}\right) \mathrm{V}\left(\mathrm{S}_{2} \mathrm{C}_{2} \mathrm{R}_{2}\right)_{2}$, is formed from $\left(\mathrm{MeC}_{5} \mathrm{H}_{4}\right)_{2} \mathrm{~V}_{2} \mathrm{~S}_{5}$ and $\mathrm{CF}_{3} \mathrm{C} \equiv \mathrm{CCF}_{3}{ }^{6}$ whereas the formation of a symmetric dithiolene bridge is accompanied by a $\eta^{1}-S_{2} \rightarrow \eta^{2}-S_{2}$ rearrangement ${ }^{8}$ (Equation 2).

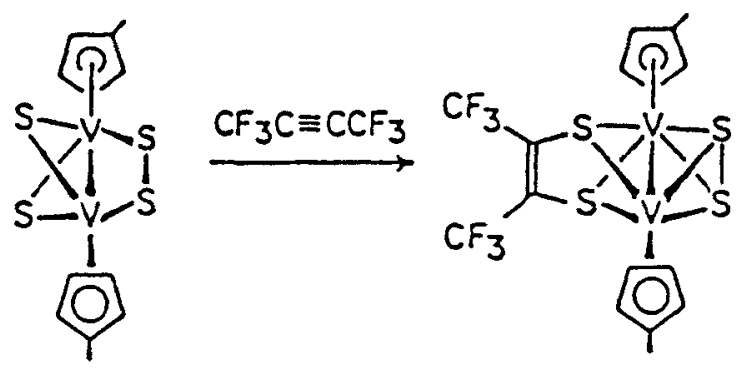

In general, the vanadium dimers appear to be less reactive than the corresponding Mo and $\mathrm{W}$ dimers. Thus, $\left(\mathrm{MeC}_{5} \mathrm{H}_{4}\right)_{2} \mathrm{Mo}_{2} \mathrm{~S}_{4}$ in both isomeric forms $\mathrm{A}$ and $\mathrm{C}$ reacts with $\mathrm{C}_{2} \mathrm{H}_{4}$ and $\mathrm{C}_{2} \mathrm{H}_{2}$ to give $\mathrm{Cp}$ dimers containing symmetrically bridging alkane- or alkenedithiolato bridges ${ }^{20,47}$

The reaction of $\mathrm{C}_{2} \mathrm{H}_{2}$ with $\left(\mathrm{C}_{5} \mathrm{H}_{5}\right)_{2} \mathrm{~W}_{2}(\mu-\mathrm{S})_{2} \mathrm{~S}_{2}$ gives dimers with terminal coordinated alkene dithiolate chelates ${ }^{47}$ Some of these compounds are of special interest for they undergo hydrocarbon exchange reactions as well as hydrogenation under mild conditions ${ }^{17,47}$ New dithiocarbonimidate bridges are formed in the reversible reaction of isocyanides with dithiolato complexes. ${ }^{48}$ Further investigations comprising monosulfur bridges in a fixed cis position ${ }^{49}$ have been directed towards the homogeneous hydrolysis of $\mathrm{CS}_{2}{ }^{50}$

$\left(\mathrm{C}_{5} \mathrm{H}_{5}\right)_{2} \mathrm{Fe}_{2} \mathrm{~S}_{4}$ gives upon reaction with $\mathrm{CF}_{3} \mathrm{C} \equiv \mathrm{CCF}_{3}$ a mono- as well as a bis-adduct, in which the bidentate 2,3-dithiolatobutene ligands are coordinated through one bridging and one terminal sulfur atom. ${ }^{33}$

Practically no attention has been paid to the nucleophilic cleavage of the S-S bond by e.g. $\mathrm{Na} / \mathrm{Hg}, \mathrm{LiEt}_{3} \mathrm{BH}$ or $\mathrm{RLi}$. These reactions lead in the case of organic disulfides or $\mathrm{Fe}_{2}(\mathrm{CO})_{6}\left(\mu-\mathrm{S}_{2}\right)$ to highly reactive anions with versatile properties. ${ }^{51}$

\subsection{Synthesis of Tri- and Tetranuclear Clusters}

$\mathrm{Cp}_{4} \mathrm{M}_{4} \mathrm{~S}_{4}$ clusters can be divided into subunits consisting of one $\mathrm{Cp}_{2} \mathrm{M}_{2} \mathrm{~S}_{4}$-and two $\mathrm{CpM}$-fragments. The hitherto developed routes for the synthesis of e.g. $\left(\mathrm{MeC}_{5} \mathrm{H}_{4}\right)_{4} \mathrm{Cr}_{4} \mathrm{~S}_{4}{ }^{52}$ (i-propC $\left.{ }_{5} \mathrm{H}_{4}\right)_{4} \mathrm{Mo}_{4} \mathrm{~S}_{4},{ }^{53}\left(\mathrm{C}_{5} \mathrm{H}_{4}\right)_{4} \mathrm{Fe}_{4} \mathrm{~S}_{4}{ }^{30}$ and $\left(\mathrm{C}_{5} \mathrm{H}_{5}\right)_{4} \mathrm{Co}_{4} \mathrm{~S}_{4}{ }^{37}$ do not refer to this consideration, for they have been obtained more or less accidentally. $\mathrm{A}$ general concept for the synthesis of homo- and heterometallic $\mathrm{M}_{4} \mathrm{~S}_{4}$-clusters has been elaborated on the basis of $\left(\mathrm{C}_{5} \mathrm{Me}_{5}\right)_{2} \mathrm{Cr}_{2} \mathrm{~S}_{5}$ and $\left(\mathrm{C}_{5} \mathrm{Me}_{5}\right)_{2} \mathrm{Mo}_{2} \mathrm{~S}_{4}$, regardless of the isomeric nature of the $\mathrm{Mo}$ 
compound. From Scheme 5 one may deduce that the $\mathrm{Cr}$ and Mo dimers serve as potential 38-e precursors which are expanded by two each of the 11-e fragments $\mathrm{MCp}$ $(\mathrm{M}=\mathrm{Cr}, \mathrm{Mo}),{ }^{54} \mathrm{Fe}(\mathrm{NO}),{ }^{55}$ or $\mathrm{Co}(\mathrm{CO})^{56}$ into 60 -electron clusters. These compounds belong to the cubane-like clusters as established by the presence of six metalmetal bonds in $\left(\mathrm{C}_{5} \mathrm{Me}_{5}\right)_{2} \mathrm{Cr}_{2} \mathrm{Co}_{2}\left(\mathrm{P}(\mathrm{OMe})_{3}\right\}_{2}\left(\mu_{3}-\mathrm{S}\right)_{4}{ }^{37}$

ำ

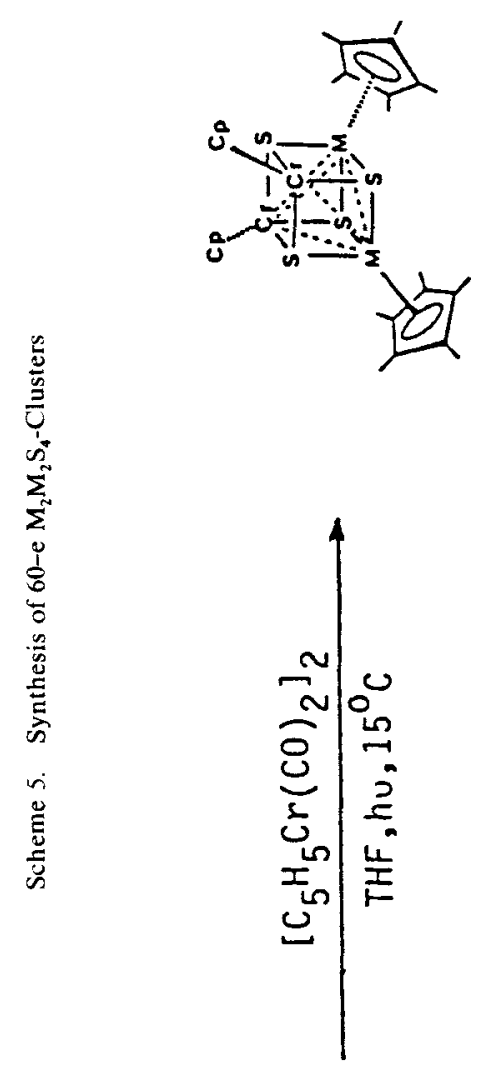

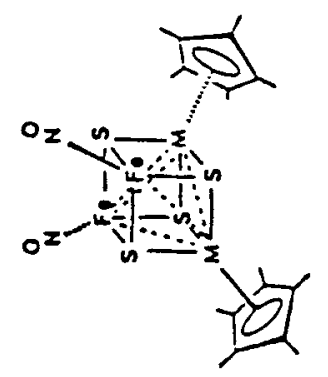

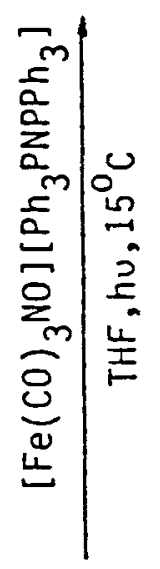

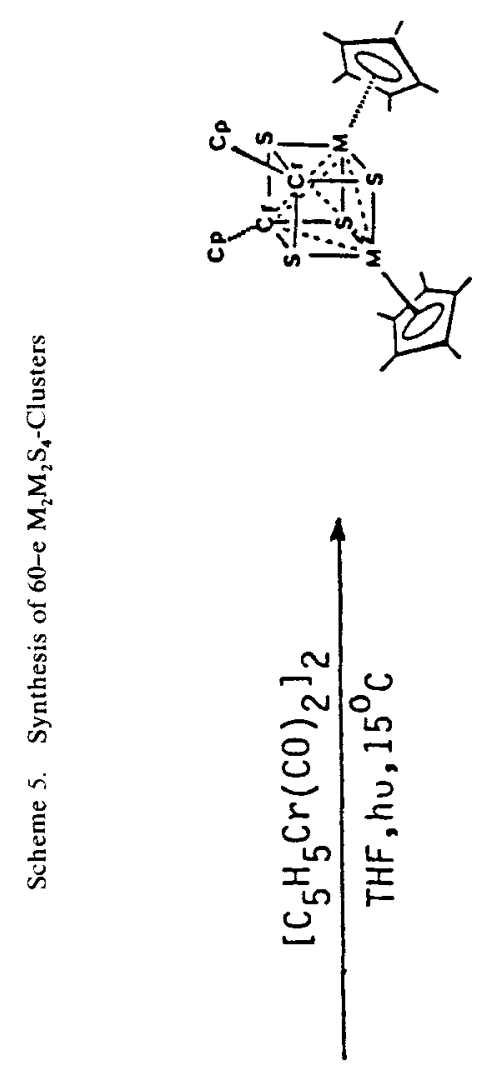

$\infty$
0
0
1
1

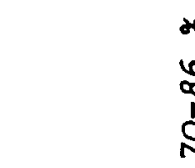

5
5
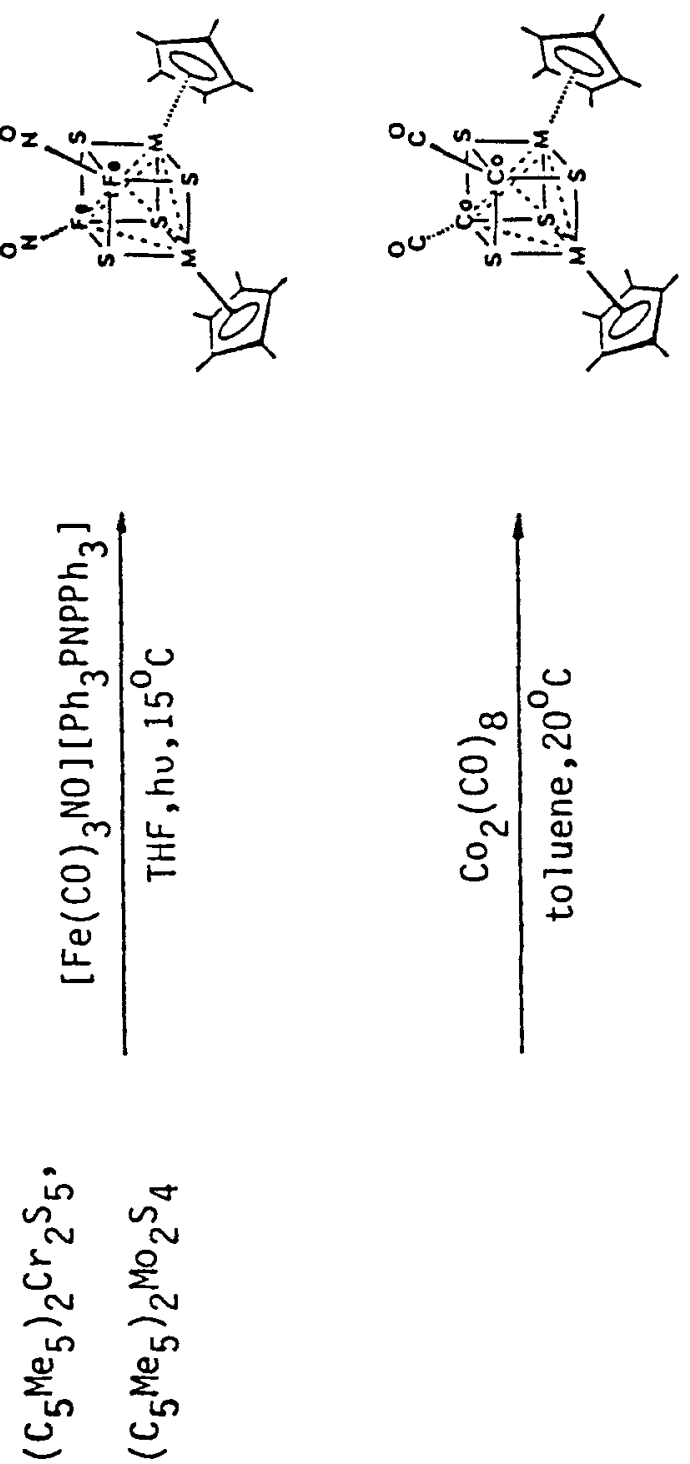
When the 12-e fragments $\mathrm{Mo}(\mathrm{CO})_{3}$ or $\mathrm{Fe}(\mathrm{CO})_{2}$ are added to $\left(\mathrm{C}_{5} \mathrm{Me}_{5}\right)_{2} \mathrm{Mo}_{2} \mathrm{~S}_{4}$, 62-e heterocubanes along with two $\mathrm{Mo}_{2} \mathrm{FeS}_{4}$ complexes (Equation 3) are formed. ${ }^{38}$ It has not been established whether the trinuclear clusters can be regarded as intermediates in the formation of the tetranuclear clusters. The remarkably mild insertion of a $\mathrm{CO}$ ligand into the $\eta^{2}-\mathrm{S}_{2}$ bridge of the dinuclear substrate cannot be achieved by a high pressure reaction of carbon monoxide with $\left(\mathrm{C}_{5} \mathrm{Me}_{5}\right)_{2} \mathrm{Mo}_{2} \mathrm{~S}_{4}$.

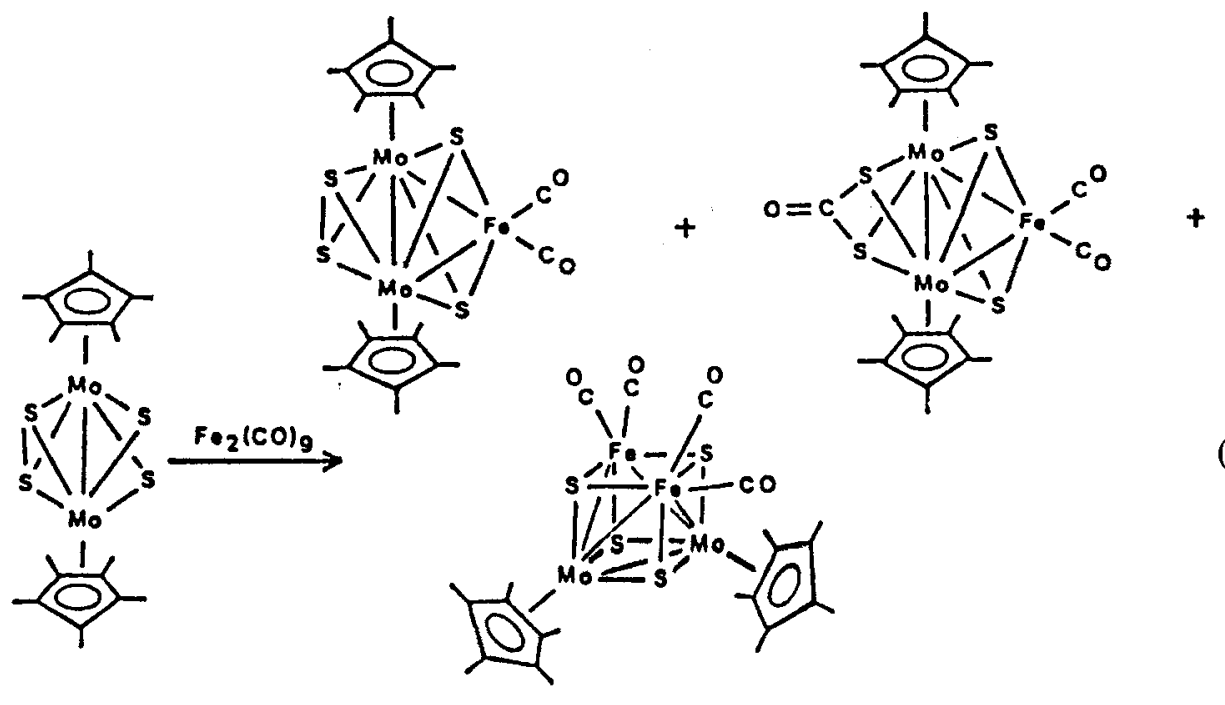

The construction of mixed oxo/thio-clusters follows the same principle as discussed above. Thus, 62-e heterocubanes can be isolated from the reaction of $\left(\mathrm{C}_{5} \mathrm{Me}_{5}\right)_{2} \mathrm{Mo}_{2} \mathrm{O}_{\mathrm{x}} \mathrm{S}_{(4-\mathrm{x})}$ $(\mathrm{x}=1,2)$ with $\mathrm{Cr}(\mathrm{CO})_{3}\left(\mathrm{CH}_{3} \mathrm{CN}\right)_{3}{ }^{59}$ (Equation 4).
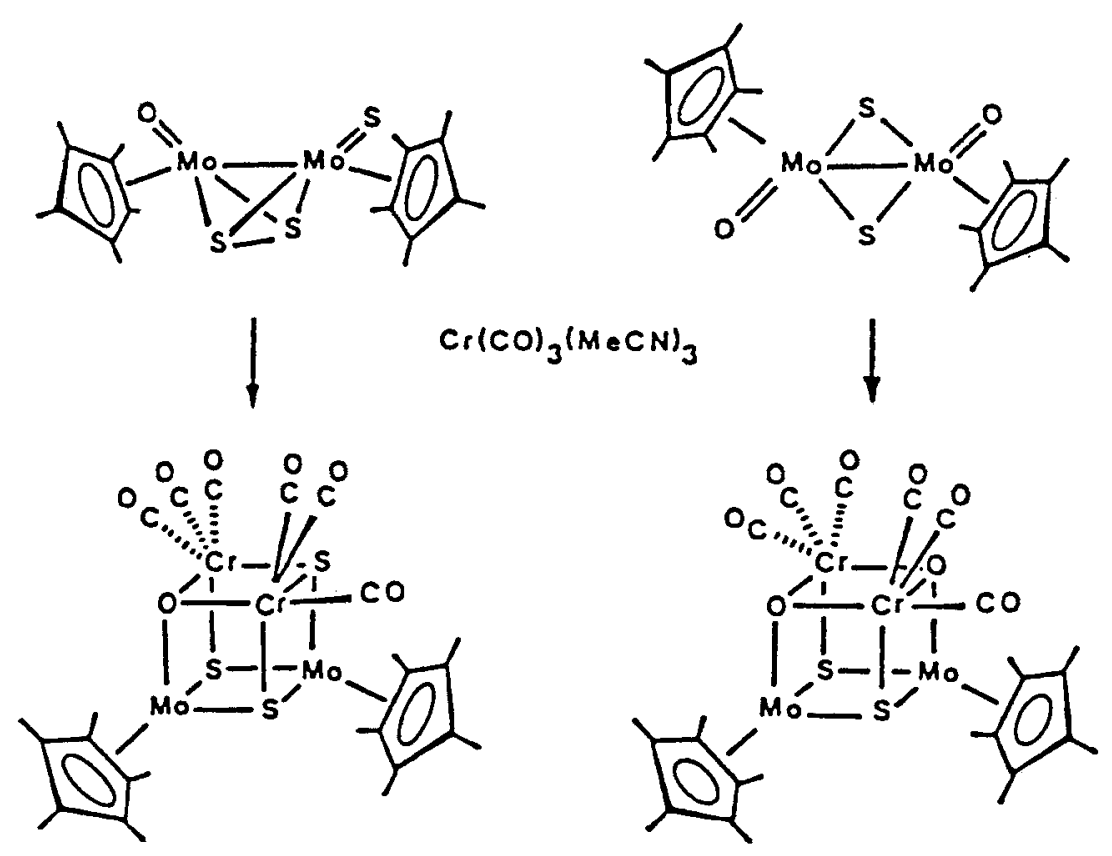
$\left(\mathrm{MeC}_{5} \mathrm{H}_{4}\right)_{2} \mathrm{~V}_{2} \mathrm{~S}_{4}{ }^{8}$ represents a potential 36-e building block for heterocubane cluster synthesis. This complex reacts with $\mathrm{Hg}\left[\mathrm{Fe}(\mathrm{CO})_{3}(\mathrm{NO})\right]_{2}$ or $\mathrm{Co}(\mathrm{CO})_{3}(\mathrm{NO})$ with formation of $\left(\mathrm{MeC}_{5} \mathrm{H}_{4}\right)_{2} \mathrm{~V}_{2} \mathrm{Fe}_{2}(\mathrm{NO})_{2} \mathrm{~S}_{4}$ (58-e) and $\left(\mathrm{MeC}_{5} \mathrm{H}_{4}\right)_{2} \mathrm{~V}_{2} \mathrm{Co}_{2}(\mathrm{NO})_{2} \mathrm{~S}_{4}$ (60-e), respectively. ${ }^{39}$ In one of these reactions the closo cluster $\left(\mathrm{MeC}_{5} \mathrm{H}_{4}\right)_{2} \mathrm{~V}_{2} \mathrm{Fe}(\mathrm{NO})_{2} \mathrm{~S}_{4}$ can be isolated at intermediate. Like $\left(\mathrm{MeC}_{5} \mathrm{H}_{4}\right)_{2} \mathrm{~V}_{2} \mathrm{Fe}(\mathrm{CO})_{3} \mathrm{~S}_{4}$ (Equation 1$)^{40}$ it contains a sideon coordinated $\eta^{2}-\mathrm{S}_{2}$ bridge. This disulfur ligand either inserts a $\left(\mathrm{PPh}_{3}\right)_{2} \mathrm{Pt}$-fragment or eliminates one sulfur atom by the interaction with $\mathrm{PBu}_{3}{ }^{40} \mathrm{~A}$ similar $\mathrm{S}$-abstraction has also been observed in the conversion of $\left(\mathrm{MeC}_{5} \mathrm{H}_{4}\right)_{2} \mathrm{~V}_{2} \mathrm{~S}_{5}$ into $\left(\mathrm{MeC}_{5} \mathrm{H}_{4}\right)_{2} \mathrm{~V}_{2} \mathrm{~S}_{5}$ into $\left(\mathrm{MeC}_{5} \mathrm{H}_{4}\right)_{2} \mathrm{~V}_{2} \mathrm{~S}_{4}$, but seems to be limited to the vanadium dimers only. ${ }^{8}$

It is of interest to compare these rather homogeneous results with cluster formation reactions of $\left(\mathrm{C}_{3} \mathrm{H}_{3}\right)_{2} \mathrm{Mo}_{2}(\mu-\mathrm{SH})_{2}(\mu-\mathrm{S})_{2}{ }^{15,16}$ which is structurally closely related to $\left(\mathrm{C}_{5} \mathrm{Me}_{5}\right)_{2} \mathrm{Mo}_{2}\left(\mu-\mathrm{S}_{2}\right)(\mu-\mathrm{S})_{2}$. However, the reactions of the hydrosulfide complex with $\mathrm{Fe}(\mathrm{CO})_{5}, \mathrm{Co}_{2}(\mathrm{CO})_{8}$, and $\mathrm{Ni}(\mathrm{CO})_{4}$ proceed in different ways (Equation 5). $\left(\mathrm{C}_{5} \mathrm{H}_{5}\right)_{2} \mathrm{Mo}_{2} \mathrm{Fe}_{2}(\mathrm{CO})_{6} \mathrm{~S}_{4}$ represents a 66 e-cluster containing a planar $\mathrm{Mo}_{2} \mathrm{Fe}_{2}$ core, ${ }^{16,60}$ whereas $\left(\mathrm{C}_{5} \mathrm{H}_{5}\right)_{2} \mathrm{Mo}_{2} \mathrm{Co}_{2}(\mathrm{CO})_{4} \mathrm{~S}_{3}$ involves a $\mu_{4}-\mathrm{S}$ bridge ${ }^{16}$ as the characteristic feature. Only $\left(\mathrm{C}_{5} \mathrm{H}_{5}\right)_{2} \mathrm{Mo}_{2} \mathrm{Ni}_{2}(\mathrm{CO})_{2} \mathrm{~S}_{4}{ }^{16}$ corresponds to the predicted 62-e cubane-like cluster type. ${ }^{38}$

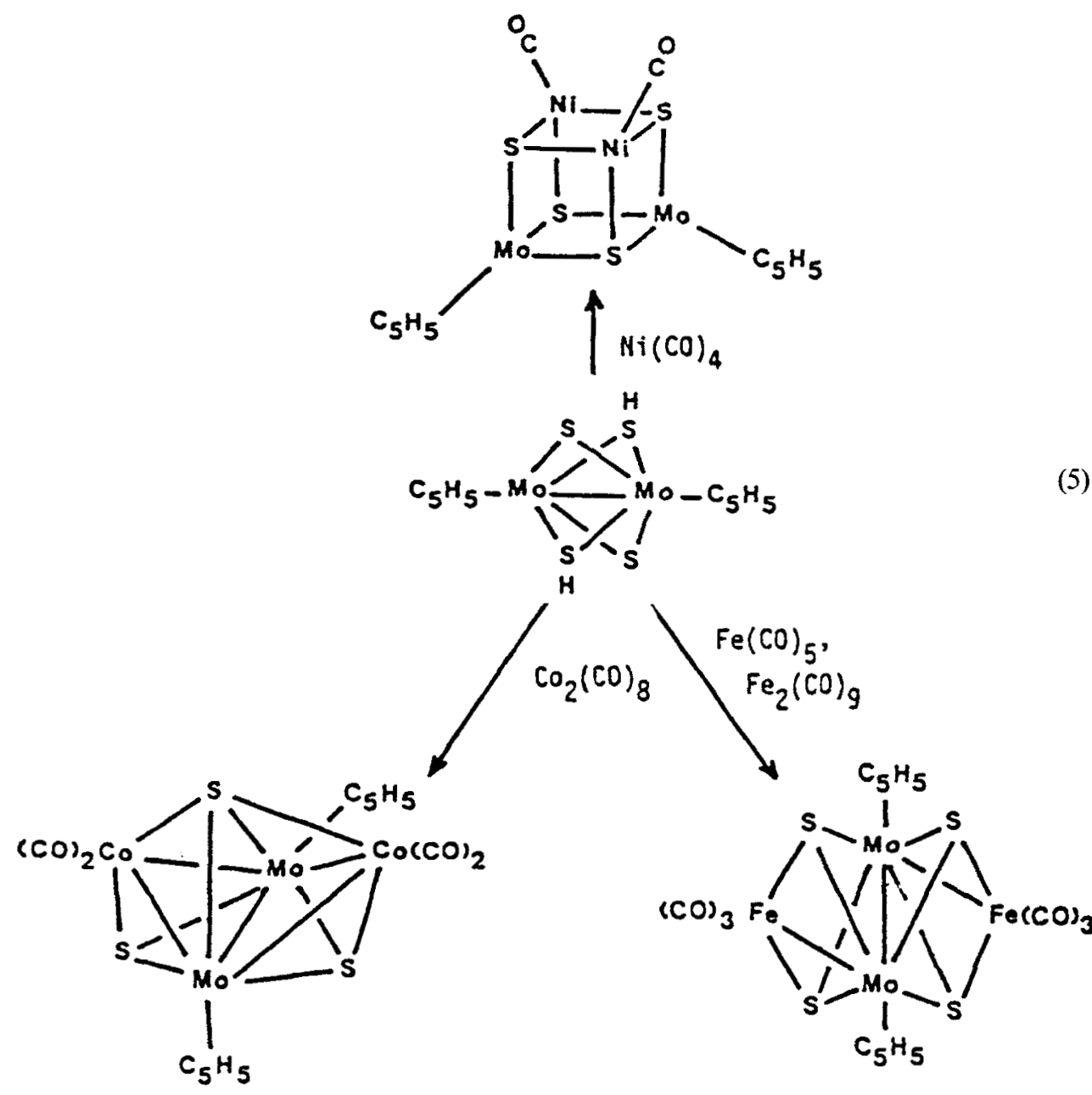




\section{DINUCLEAR CYCLOPENTADIENYL COMPLEXES OF THE OTHER CHALCOGENIDES}

It may be of interest to compare the chemistry of the bis(cyclopentadienyl transition metal) sulfides with that of the other calcogenides. Among these selenium shows ligating properties closely related to sulfur. Thus, examples for mono- and di-selenium ligands are known from the literature which might also occur in hypothetical $\mathrm{Cp}_{2} \mathrm{M}_{2} \mathrm{Se}_{4^{-}}$or $-\mathrm{Se}_{3}$ complexes: $\mu$-Se-, ${ }^{61,62} \mu, \eta^{1}-\mathrm{Se}_{2}{ }^{28}{ }^{28} \mu, \eta^{2}-\mathrm{Se}_{2}{ }^{-63}$ and $\mu\left(\eta^{1}, \eta^{2}\right)-\mathrm{Se}_{2}-$ ligands. ${ }^{64}$ Combinations of these ligands are found in $\left(\mathrm{C}_{5} \mathrm{Me}_{5}\right)_{2} \mathrm{Mo}_{2}\left(\mu-\mathrm{Se}_{2}\right)(\mu-\mathrm{Se})_{2}$, $\left(\mathrm{C}_{3} \mathrm{Me}_{5}\right)_{2} \mathrm{Mo}_{2}(\mu-\mathrm{Se})_{2} \mathrm{O}_{2}$, and $\left(\mathrm{C}_{5} \mathrm{Me}_{5}\right)_{2}(\mathrm{CO})_{2} \mathrm{~W}_{2}(\mu-\mathrm{Se})_{2} \mathrm{Se}$, which are accessible from $\left(\mathrm{C}_{5} \mathrm{Me}_{5}\right)_{2} \mathrm{M}_{2}(\mathrm{CO})_{4}(\mathrm{M}=\mathrm{Mo}, \mathrm{W})$ and elemental selenium. ${ }^{65} \mathrm{~A}$ complex of composition $\left(\mathrm{C}_{5} \mathrm{Me}_{3}\right)_{2} \mathrm{Co}_{2} \mathrm{Se}_{3}$ has also been reported, but not structurally characterized. ${ }^{66} \mathrm{Condensed}$ selenium vapor can also be used to synthesize thermally unstable, still $\mathrm{CO}$ containing complexes of Mo and $\mathrm{W}^{26}$

Efforts for the incorporation of elemental tellurium have been so far directed towards metal carbonyl derivatives only. The stabilization of several (although limited) examples of $\mu$-Te ligands with nucleophilic characte ${ }^{67}$ as well as $T_{2}$-ligands ${ }^{68}$ may be indicative of the existence of tellurium complexes fulfilling the conditions for this review.

As already described in section 3.1 oxygen is able to displace terminal $\mathrm{S}^{2-}$ ligands from Mo centers. Although the complexes $\left(\mathrm{C}_{5} \mathrm{H}_{5}\right)_{2} \mathrm{Mo}_{2}\left(\mu-\mathrm{O}_{2} \mathrm{O}_{2}\right.$ and $\left(\mathrm{C}_{5} \mathrm{H}_{5}\right)_{2} \mathrm{Mo}_{2}(\mu-\mathrm{O}) \mathrm{O}_{4}$ synthesized some years ago, ${ }^{69}$ a systematic oxidation reaction of $\mathrm{Cp}$ metal carbonyls has been initiated only very recently, leading to $\left(\mathrm{C}_{5} \mathrm{H}_{5}\right)_{2} \mathrm{Cr}_{2} \mathrm{O}_{4}{ }^{70}\left(\mathrm{C}_{5} \mathrm{Me}_{5}\right)_{2} \mathrm{Mo}_{2} \mathrm{O}_{4}{ }^{71}$ $\left(\mathrm{C}_{3} \mathrm{Me}_{5}\right)_{2}-\mathrm{Mo}_{2} \mathrm{O}_{5},{ }^{70}$ and $\left(\mathrm{C}_{3} \mathrm{Me}_{3}\right)_{2} \mathrm{Re}_{2} \mathrm{O}_{4}{ }^{72}$ The results of crystallographic studies (Scheme 6) show that oxygen ligands induce higher oxidation states at the metal centers than sulfur ligands and that new structural types can be realized which have not vet been found for $\mathrm{Cp}_{3} \mathrm{M}_{2} \mathrm{~S}_{4}$ compounds.

\section{Scheme 6}
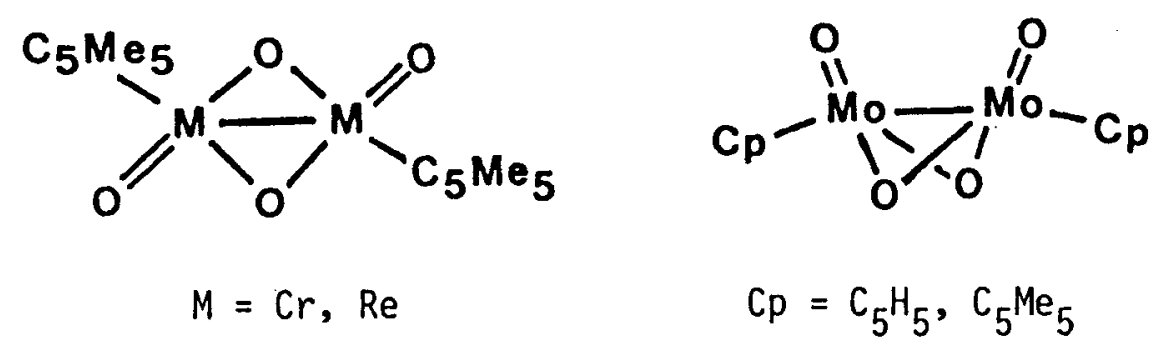

\section{FINAL REMARKS}

Rational, general synthetic techniques have been developed for the stabilization of mono- and disulfur ligands in dinuclear cyclopentadienyl transition metal complexes. These compounds differ significantly in their structures and exhibit interesting reactivity patterns. Most of the sulfur-rich transition metal cyclopentadienides presented in this review belong to first row transition metals. However, the results obtained in the chromium triad indicate that changes in structures and reactivity may be expected when going from $3 \mathrm{~d}$ to $4 \mathrm{~d}$ and $5 \mathrm{~d}$ elements.

Whereas the synthesis of new sulfur ligands ${ }^{3}$ or the realization of new coordination modes for already known ligands appears to be more and more difficult, a transfer of this knowledge to the other chalcogenes should be attempted. Another motivation for the synthesis of new ligands being unstable under normal conditions may arise from 
several new exciting $\mathrm{Cp}$ complexes containing "inorganic" phosphorus or arsenic ligands. ${ }^{73}$ Some of these molecules resemble in their structures $C \mathrm{p}_{2} \mathrm{M}_{2}$ sulfides. As a first impulse in this direction the stabilization of $\mathrm{AsS}_{3}-{ }^{74} \mathrm{AsS}_{-}{ }^{75} \mathrm{As}_{2} \mathrm{~S}-{ }^{76}$ or $\mathrm{As}_{2} \mathrm{~S}_{3}-$-ligands ${ }^{77}$ from $\mathrm{As}_{4} \mathrm{~S}_{4}$ by different $\mathrm{CpM}$ fragments may be considered.

\section{REFERENCES}

H. Vahrenkamp, Angew. Chem. Int. Ed. Engl 14, 322 (1975).

A. Müller, W. Jaegermann. J.H. Enemark. Coord. Chem. Rev. 46, 245 (1982).

M. Draganjac, T.B. Rauchfuss, Angew. Chem. Int. Ed. Engl. 24, 742 (1985).

RA. Schunn, C.J. Fritchie Jr., C.T. Prewitt. Inorg. Chem. 5, 892 (1966).

KG. Muller, J.L. Petersen, L.F. Dahl, J. Organomet. Chem. 111, 91 (1976).

C.M. Bolinger, T.B. Rauchfuss, A.L. Rheingold. Organometallics 1, 1551 (1982)

D.M. Giolando. T.B. Rauchfuss. J. Am. Chem. Soc. 106, 6455 (1984).

C.M. Bolinger, T.B. Rauchfuss, A.L. Rheingold, J. Am. Chem. Soc. 105, 6321 (1983).

W.A. Herrmann, H. Biersack, M.L. Ziegler, B. Balbach, J. Organomet. Chem. 206, C33 (1981).

H. Brunner, J. Wachter, E. Guggolz, M.L. Ziegler, J. Am. Chem. Soc. 104, 1765 (1982).

L.Y. Goh, T.W. Hambley, G.B. Robertson, J. Chem. Soc. Chem. Commun. 1458 (1983).

H. Brunner. H. Kauermann, W. Meier. J. Wachter, J. Organomet. Chem. 263, 183 (1984).

H. Brunner, W. Meier, J. Wachter, E. Guggolz. T. Zahn, M.L. Ziegler, Organometallics 1, 1107 (1982).

M.D. Curtis. W.M. Butler. J. Chem. Soc. Chem. Commun. 998 (1980).

15. M. Rakowski DuBois, M.C VanDerveer. D.L. DuBois, R.C. Haltiwanger, W.K. Miller, J. Am. Chem. Soc. 102, 7456 (1980).

16. M.D. Curtis, P.D. Williams, Inorg. Chem. 19, 2661 (1983).

17. D.L. DuBois, W.K. Miller, M. Rakowski DuBois, J. Am. Chem. Soc. 103, 3429 (1981).

18. W. Beck. W. Danzer, G. Thiel, Angew. Chem. Int. Ed. Engl. 12, 582 (1973); W. Danzer, W.P. Fehlhammer, A.T. Liu, G. Thiel, W. Beck, Chem. Ber. 115, 1682 (1982).

19. M. Rakowski DuBois, R.C. Haltiwanger, D.J. Miller, G. Glatzmeier, J. Am. Chem. Soc. 101, 5245 (1979).

20. M. Rakowski DuBois. D.L. DuBois. M.C. VanDerveer. R.C. Haltiwanger, Inorg. Chem. 20, 3064 (1981).

21. S. Lincoln. S.-L. Soong. S.A. Koch. M. Sato. J.H. Enemark, Inorg. Chem. 24, 1355 (1985).

22. A.E. Bruce. D.R. Tyler. Inorg. Chem. 23, 3433 (1984).

J.M. Newsam. T.R. Halbert. Inorg. Chem. 24, 491 (1985).

M. Herberhold, W. Jellen. H.M. Murray, J. Organomet. Chem. 270, 65 (1984).

G.J. Kubas, H.J. Wasserman. R.R. Ryan, Organometallics 4, 419 (1985).

K. Endrich. Thesis 1986, University of Heidelberg.

R.B. King. M.Z. Iqbal, A.D. King Jr., J. Organomet. Chem. 171, 53 (1979).

28. M. Herberhold, D. Reiner, B. Zimmer-Gasser, U. Schubert, Z. Naturforsch. 35b, 1281 (1980); M. Herberhold. D. Reiner. K. Ackermann. U. Thewalt. T. Debaerdemaeker, Z. Naturforsch. 39b, 1199 (1984).

29. J. Wachter, unpublished results.

30. C.H. Wei, G.R. Wilkes, P.M. Treichel, L.F. Dahl, Inorg. Chem. 5, 900 (1966)

31. M.A. El-Hinnawi. A.A. Aruffo. B.D. Santarsiero. R. McAlister. V. Schomaker, Inorg. Chem. 22, 1585 (1983).

32. H. Chanaud. A.M. Ducourant. C. Giannotti, J. Organomet. Chem. 190, 201 (1980).

33. R. Weberg. R.C. Haltiwanger. M. Rakowski DuBois. Organometallics 4, 1315 (1985).

34. H. Brunner, N. Janietz. W. Meier, G. Sergeson. J. Wachter, T. Zahn, M.L. Ziegler, Angew. Chem. Int. Ed. Engl., 24, 1060 (1985).

35. PJ. Vergamini, R. Ryan, G. Kubas, J. Am. Chem. Soc. 98, 1980 (1976).

36. P.D. Frisch. L.F. Dahl. J. Am. Chem. Soc. 94, 5082 (1979).

37. G.L. Simon, L.F. Dahl, J. Am. Chem. Soc. 95, 2164 (1973).

38. C.M. Bolinger. T.B. Rauchfuss, S.R. Wilson, J. Am. Chem. Soc. 106, 7800 (1984).

39. T.B. Rauchfuss, T.D. Weatherhill, S.R. Wilson, J.P. Zebrowski, J. Am. Chem. Soc. 105, 6508 (1983).

40. C.M. Bolinger, T.B. Rauchfuss, S.R. Wilson, J. Am. Chem. Soc. 104, 7313 (1982).

41. G.J. Kubas, R.R. Ryan, J. Am. Chem. Soc. 107, 6138 (1985).

42. C.G. Young, M. Minelli. J.H. Enemark, G. Miessler, N. Janietz, K. Kauermann, J. Wachter, Polyhedron, in press.

43. D.L. Stevenson, L.F. Dahl. J. Am. Chem. Soc. 89, 3721 (1967).

44. J. Messelhäuser. J. Kull. I.-P. Lorenz, XIl Int. Conf. Organomet Chem. Abstracts 75 (1985).

45. J.E. Hoots, D.A. Lesch, T.B. Rauchfuss, Inorg. Chem. 23, 3130 (1984)

46. G. Schmid. G. Ritter, Angew. Chem. Int Ed. Engl. 14,645 (1975); B. Schmidkonz, M. Herberhold, XII Int. Conf. Organomet Chem. Abstracts 231 (1985). 
47. D.A Rajan, M. McKenna, J. Noordik, R.C. Haltiwanger, M. Rakowski DuBois, Organometallics 3, 831 (1984).

48. D.J. Miller, M. Rakowski DuBois, J. Am. Chem. Soc. 102, 4925 (1980).

49. M. McKenna, L.L. Wright, D.J. Miller, L. Tanner, R.C. Haltiwanger, M. Rakowski DuBois, J. Am. Chem. Soc. 105, 5329 (1983).

50. M. Rakowski DuBois, J. Am. Chem. Soc. 105, 3710 (1983).

51. D. Seyferth, R.S. Henderson, L.-C. Song, J. Am. Chem. Soc. 103, 5103 (1981); D. Seyferth, R.S. Henderson, L.-C. Song, Organometallics 1, 125 (1982).

52. A.A. Pasynskii, I.L. Eremenko, Y.V. Rakitin, V.M. Novotortsev, O.G. Ellert, V.T. Kalinnikov, V.E. Shklover, Y.T. Struchkov, S.V. Lindeman, T.K. Kurbanov, G.S. Gasanov, J. Organomet Chem. 248, 309 (1983).

53. J.A. Bandy, C.E. Davies, J.C. Green, M.L.H. Green, K. Prout, D.P.S. Rodgers, J. Chem. Soc. Chem. Commun. 1395 (1983).

54. H. Brunner, H. Kauermann, J. Wachter, J. Organomet. Chem. 265, 189 (1984)

55. H. Brunner, H. Kauermann, J. Wachter, Angew. Chem. Int. Ed. Engl. 22, 549 (1983).

56. H. Brunner, J. Wachter, J. Organomet. Chem. 240, C41 (1982).

57. H. Brunner, W. Meier, J. Wachter, H. Pfisterer, M.L. Ziegler, Z. Naturforsch. 40b, 923 (1985).

58. H. Brunner, N. Janietz, J. Wachter, T. Zahn, M.L. Ziegler, Angew. Chem. Int. Ed. Engl. 24, 133 (1985).

59. H. Kauermann, Thesis 1985, University of Regensburg.

60. B. Cowans, J. Noordik, M. Rakowski DuBois, Organometallics 2, 931 (1983).

61. M.A. Jennings, A. Wojcicki,J. Organomet. Chem. 14,231 (1968); W.A. Herrmann, C. Bauer, J. Weichmann, Chem. Ber. 117, 1271 (1984).

62. G. Tainturier, B. Gautheron, M. Fahim, J. Organomet Chem. 290, C4 (1985).

63. W. Hieber, J. Gruber, Z. Anorg. Allg. Chem. 296, 91 (1958); C.F. Campana, F.Y.-K Lo, L.F. Dahl, Inorg. Chem. 18, 3060 (1979); A.J. Benton, M.G.B. Drew, D.A. Rice, J. Chem. Soc. Chem. Commun. 1241 (1981); M.G.B. Drew, D.A. Rice, D.M. Williams,J. Chem. Soc. Dalton 1087 (1984); W.A. Herrmann, J. Rohrmann, H. Nöth, C.K. Nanila, I. Bernal, M. Draux, J. Organomet. Chem. 284, 189 (1985).

64. C. Bianchini, C. Mealli, A. Meli, M. Sabat, J. Am. Chem. Soc. 107, 5317 (1985).

65. H. Brunner, J. Wachter, H. Wintergerst, J. Organomet. Chem. 235, 77 (1982).

66. J. Weichmann, Thesis 1983, University of Frankfurt.

67. W.A. Herrmann, J. Rohrmann, C. Hecht, J. Organomet Chem. 290, 53 (1985).

68. D.A. Lesch, T.B. Rauchfuss, Inorg. Chem. 20, 3538 (1981); O. Scheidsteger, G. Huttner, K. Dehnicke, J. Pebler, Angew. Chem. Int Ed. Engl. 24, 428 (1985); L.E. Bogan Jr., T.B. Rauchfuss, A.L. Rheingold, Inorg. Chem. 24, 3720 (1985).

69. M. Cousins, M.L.H. Green, J. Chem. Soc. 1567 (1964); C. Couldwell, K. Prout, Acta Crystallogr. B34, 933 (1978).

70. M. Herberhold, W. Kremnitz, U. Thewalh, A Razavi, H. Schöllhorn, Angew. Chem. Int. Ed. Engl. 24, 601 (1985).

71. H. Arzoumanian, A Baldy, M. Pierrot, J.-F. Petrignani, J. Organomet. Chem. 294, 327 (1985)

72. W.A. Herrmann, R Serrano, H. Bock, Angew. Chem. Int. Ed. Engl. 23, 383 (1984); W.A. Herrmann, R. Serrano, U. Küsthardt, M.L. Ziegler, E. Guggolz, T. Zahn, ibid. 23, 515 (1984).

73. A.L. Rheingold, M.J. Foley, P.J. Sullivan, J. Am. Chem. Soc. 104, 4727 (1982); O.J. Scherer, H. Sitzmann, G. Wolmershäuser, Angew. Chem. Int. Ed. Engl. 24, 351 (1985); O.J. Scherer, ibid. 24, 924 (1985).

74. G.A. Zank, T.B. Rauchfuss, S.R. Wilson, A.L. Rheingold, J. Am. Chem. Soc. 106, 7621 (1984).

75. H. Brunner, H. Kauermann, U. Klement, J. Wachter, T. Zahn, M.L. Ziegler, Angew. Chem. Int Ed. Engl. 24, $132(1985)$.

76. I. Bernal, H. Brunner, W. Meier, H. Pfisterer, J. Wachter, M.L. Ziegler, Angew. Chem. Int Ed. Engl. 23, 438 (1984); M. Di Vaira, F. Mani, S. Moneti, M. Perruzini, L. Sacconi, P. Stoppioni, Inorg. Chem. 24, 2230 (1985).

77. H. Brunner, H. Kauermann, J. Wachter, B. Nuber, M.L. Ziegler, Anorg. Chem. in press. 